\title{
Vestal Virgins and Their Families
}

\author{
Andrew B. Gallia*
}

\section{INTRODUCTION}

There is perhaps no more shining example of the extent to which the field of Roman studies has been enriched by a renewed engagement with anthropology and other cognate disciplines than the efflorescence of interest in the Vestal virgins that has followed Mary Beard's path-breaking article regarding these priestesses" "sexual status."1 No longer content to treat the privileges and ritual obligations of this priesthood as the vestiges of some original position (whether as wives or daughters) in the household of the early Roman kings, scholars now interrogate these features as part of the broader frameworks of social and cultural meaning through which Roman concepts of family,

* Published in Classical Antiquity 34.1 (2015).

Early versions of this article were inflicted upon audiences in Berkeley and Minneapolis. I wish to thank the participants of those colloquia for helpful and judicious feedback, especially Ruth Karras, Darcy Krasne, Carlos Noreña, J. B. Shank, and Barbara Welke. I am also indebted to George Sheets, who read a penultimate draft, and to Alain Gowing and the anonymous readers for $C A$, who prompted additional improvements. None of the above should be held accountable for the views expressed or any errors that remain.

${ }^{1}$ Beard 1980, cited approvingly by, e.g., Hopkins 1983: 18, Hallett 1984: x, Brown 1988:

8, Schultz 2012: 122. Critiques: Gardner 1986: 24-25, Beard 1995. 
gender, and religion were produced. ${ }^{2}$ This shift, from a quasi-diachronic perspective, which seeks explanations for recorded phenomena in the conditions of an imagined past, to a more synchronic approach, in which contemporary contexts are emphasized, represents a welcome methodological advance. As H. N. Parker points out, "the search for origins or etymologies does not in itself constitute an explanation of the god, myth, or ritual. The very fact of the 'survival' and the reasons for it must be explained" (2004: 565). Assuming it could be proved that the sacral duties of the Vestal virgins reproduced those of the daughters (or brides) of the kings, we would still need to try to understand why these functions remained an integral part of Roman religious life long after the kings were gone.

The trouble, as always, is that we do not have the depth of documentation necessary to achieve a genuinely synchronic overview of any one moment in the long history of the Vestal priesthood. Because fieldwork among native informants is out of the question, anthropologically-minded Romanists are forced to mine for data in sources of widely varying date and to put faith in the claims of the ancient antiquarians and jurists, who have done much of this mining for us already. As the material is stitched together, the messy particulars of its original historical contexts begin to fade away, often to the point where the resulting picture of Roman society becomes that of a static ideal, from which the conflicts and ambiguities that drove institutions to change over time have been

${ }^{2}$ Holland 2012: 209. For examples of the previous approach, see Jordan 1886: 43-56, Santinelli 1904: 73-76, Rose 1926, Latte 1960: 108-11, also Hallett 1984: 84-85, 126; cf. Brelich 1949: 57-66. 
erased. Needless to say, the theoretical principles that emerge from such a method provide only limited insight into the lived experience of actual Vestals, with the result that the explanatory force they provide sometimes is no more compelling than that of the aetiological narratives propounded by earlier generations of scholars.

This gulf between historical reality and the scholarly description of it has become particularly apparent in certain accounts of the Vestals' position with regard to the normative structures of Roman kinship. There is no denying that the Vestal virgins stood apart from other women in this, as in many other aspects of their identity. The strict enforcement of total chastity during their thirty years of service obviously prevented the Vestals from becoming wives and mothers, for one thing. In the years that have followed Beard's seminal contribution, however, a number of (mostly anglophone) scholars have come to place increasing emphasis on the process, described by Aulus Gellius (NA 1.12), whereby a young girl was "captured" (capta) by the pontifex maximus in the course of her entry into the priesthood. Because this "capture" ended the father's authority (potestas) over his daughter without placing her under the control (manus) of a husband or into the legal guardianship (tutela) of another male agnate, it is sometimes assumed that the purpose of this ritual was to further debar these priestesses from occupying any recognizable position within a Roman family. In recent decades, this concept of the Vestals' isolation from traditional kinship roles has become central to a broad array of 
interpretative frameworks, each of them offering to explain the priestesses' religious identity as a function of their position within Roman society as a whole. ${ }^{3}$

Less widely acknowledged in this context is the extent to which these arguments overlook a considerable body of evidence that clearly suggests that the Vestal virgins continued to behave as if they were still connected by meaningful bonds of kinship with the families into which they had been born. ${ }^{4}$ This article presents a new account of the Vestals' kinship status, along with the necessary reconsideration of the various claims that have been launched on the basis of a purely notional, rather than real, image of the Vestals as standing apart from family ties. I want to stress at the outset that my dissatisfaction with the arguments I have singled out for criticism does not involve any repudiation of the anthropological approach itself or even necessarily of the specific theoretical insights that their proponents have tried to bring to bear. I am entirely in sympathy with these efforts to understand the peculiarities and taboos surrounding the Vestal priesthood as part of a larger framework of cultural meaning. It is not an issue of returning to some scholarly status quo ante or of replacing a flawed approach with something better. Rather, the redress I am looking for in this article stems from my

${ }^{3}$ Beard 1980: 21, Cancik-Lindemaier 1990: 14-15, Staples 1998: 143-45, Parker 2004: 572-73, Kroppenberg 2010: 435. See further below, Section IV. Acceptance of this view is not universal, however. Schultz 2006: 78 explicitly highlights the "continuing importance of familial links for Vestals."

${ }^{4}$ Cf. Staples 1998: 144, where these links are acknowledge only to be dismissed; see further below, section III.A. 
interest in the methodological problem of how we should account for the (admittedly diffuse and ambivalent) evidence of lived experience without either overlooking or unduly privileging the proscriptive claims that appear in the legal and antiquarian sources. Legal precepts undoubtedly represent an important source of information for cultural norms and expectations, but I am also persuaded by the argument that individual expressions of so-called "affective" bonds must also be considered if we want to understand the nature of the family as an institution embedded in Roman culture. ${ }^{5}$

I readily acknowledge that the underlying logic of the Roman cultural system was not necessarily apparent to those whose lives were shaped by it. We should not insist that our explanation for these practices rest upon the positive evidence of some explicit statement by Cicero or another ancient authority. ${ }^{6}$ On the other hand, given the fragmentary and often tendentious nature of our evidence, we cannot rely upon a purely theoretical or formal approach either. Taking my cue from Clifford Geertz (1973: 94), I contend that the best way to understand the nature of Roman culture is to observe it in action. To this end, my discussion begins with a brief, narrative survey of what we know about the interaction between individual Vestals and their families. I show how, in instance after instance, the Vestals maintained close ties with their agnatic kin. In the

\footnotetext{
${ }^{5}$ Saller and Shaw 1984, Shaw 1991, Dixon 1991.

${ }^{6}$ Beard 1980: 26: "the underlying logic behind a particular cult practice need not be, and often is not, appreciated in the conscious thought of the actors themselves, yet this apparent unawareness does not invalidate the type of explanation I have undertaken." Cf. Douglas 1969: 173-74.
} 
second part, I take up the issue of the priestesses" "capture" and consider how we might reconcile the experiences of real Vestals with the unusual legal status ascribed to them by Aulus Gellius and others. Drawing on the insights of Black feminist criticism, I argue that the source of these legal anomalies lies not in the underlying design of Roman concepts of the sacred, but rather in the unique intersection of categories presented by the Vestal's priestly authority and their gender. As a practical expedient, the "capture" of these virgins is best seen as the means by which their status was assimilated to that of the other priests under the purview of the pontifical college. The privileges thus acquired made the Vestals unusual as women, but did not necessarily diminish the importance of their social identity as female members of a Roman family.

In the final section of the paper, I turn to the problem of the Vestal's virginity, which remains the single most anomalous feature of their social position. A reexamination of the arguments of those scholars who would place greater emphasis on the supposed removal of the Vestals from their families of origin highlights the distorting influence of these attempts to conflate the priestesses' extraordinary sexual purity with other, less problematic aspects of their gender identity. Rather than dismiss these contributions out of hand, I consider whether the theoretical frameworks from which they are derived might still be accommodated, mutatis mutandis, to the perspective developed here. The conclusion recapitulates the significance of the Vestal's status as unmarried females in a culture that valued women primarily as mothers and wives.

\section{DAUGHTERS, SISTERS, AND AUNTS: A NARRATIVE OVERVIEW}




\section{A. THE REPUBLIC}

As is the case with so much of our evidence for social conditions under the

Roman Republic, the documentation for the relationship between Vestal virgins and their families of origin during this period is fragmentary and largely anecdotal. Many times, it was only when bonds of loyalty expressed themselves through some striking intervention into the realm of political affairs that our sources are apt to take notice of them. Caution is needed in dealing with such material, of course. Generalizing from scattered, extraordinary cases can be dangerous, but if the alternative is to sweep them under the rug, it is better to at least try to account for what these episodes can tell us.

The earliest known instance of a Vestal interceding on behalf of a member of her family dates to $143 \mathrm{BC}$, when the consul Appius Claudius Pulcher decided to celebrate a triumph after his problematic victory over the Salassi. ${ }^{7}$ Valerius Maximus describes the actions of his daughter, the Vestal Claudia, in his collection of Memorable Deeds and Sayings:

quae, cum patrem suum triumphantem e curru violenta tribuni $<$ pl. $>$ manu $<$ detrahi $>$ animadvertisset, mira celeritate utrisque se interponendo amplissimam potestatem inimicitiis accensam depulit. igitur alterum triumphum pater in

${ }^{7}$ Münzer 1937: 47-48, Hallett 1984: 89, Bauman 1992: 47, Scardigli 2003: 100, Wildfang 2006: 91-92, see also Beard 2007: 204. Sources in Broughton 1951: 471, Rüpke 2005: 874 no. 1152. 
Capitolium, alterum filia in aedem Vestae duxit, nec discerni potuit utri plus laudis tribueretur, cui victoria an cui pietas comes aderat.

Val. Max. 5.4.6

When she saw her father in this triumph being dragged from the chariot by the outrageous hand of a tribune of the people, she overcame the magistrate's enormous power, which had been roused by hostility, by placing herself between the two with marvelous speed. Thus, the father led one triumph to the Capitol, the daughter another to the temple of Vesta, and it cannot be resolved who earned more praise: the one whom Victory accompanied, or the one whose companion was Piety.

By interposing her own religious authority against that of the tribune of the plebs (whose person was also sacrosanct), Claudia resolved her father's legal predicament, making it possible for him to enjoy the glory of a triumph that otherwise would have been denied him. Whether she did this of her own accord or at the prompting of her ambitious father, her actions suggest a continued commitment to the public prestige of her famously proud family. Valerius goes so far as to describe her exemplum as potentially a "stronger and more courageous" (valentius et animosius) display of filial pietas than that shown by any son.

A similar attempt by a Vestal virgin to use her influence to benefit a member of her immediate family can be seen in the trial of M. Fonteius, who was accused of corruption following his three years of service as propraetor in Gaul during the late $70 \mathrm{~s}$ 
BC. According to the peroration of Cicero's speech for the defense, Fonteius benefitted from the presence of his sister, a Vestal virgin, in the court. ${ }^{8}$ Far from being severed by her entry into priestly office, Fonteia's bond with her brother could even be said to have strengthened, as she embraced him and implored the jury for mercy on his behalf. Cicero goes on to explain her motivations:

cui miserae quod praesidium, quod solacium reliquum est hoc amisso? nam ceterae feminae gignere ipsae sibi praesidia et habere domi fortunarum omnium socium participemque possunt; huic vero virgini quid est praeter fratrem quod aut iucundum aut carum esse possit?

Cic. Font. 47

What other security, what solace, is left to this poor woman if he is lost? Whereas other women can bear children as their security and have an ally and partner in their own household, what can this true virgin have besides her brother that is either pleasant or dear to her?

According to the logic of this emotional appeal, the important difference between Vestal virgins and other women was that Vestals were likely to become even more dependent upon their agnatic relations, insofar as they could not rely upon husbands or children to

${ }^{8}$ Cic. Font. 46-49; Hallett 1984: 89, North 2000: 360-64, Scardigli 2003: 101, Rüpke 2005: 966 no. 1577. 
take care of them. In fact, as we will see in the following section, Vestals were probably not as helpless as other women might be in their position. The point remains, however, that Fonteia's intervention on behalf of her brother was regarded as a normal manifestation of his continued importance in her life.

Whatever comfort these priestesses might find in family, male relatives could also expect to benefit from the influence and prestige of their Vestal kin. Cicero's speech for Fonteius culminates in a chauvinistic admonition to the jurors to "take care ... that the prayers of a Vestal virgin should be seen to have more weight with you than the threats of Gauls" (postremo prospicite, iudices, ... ut plus apud vos preces virginis Vestalis quam minae Gallorum valuisse videantur, Cic. Font. 49). Another of Cicero's defendants, L. Licinius Murena, sought to raise his profile during his campaign for the consulship in 63 BC by taking advantage of the special seats that "his kinswoman and near relation" (huius propinqua et necessaria, Mur. 73) was granted at the gladiatorial games in her capacity as a Vestal virgin. ${ }^{9}$ This seems to have been the same Licinia whose business dealings with another relative, M. Licinius Crassus, had given rise to an accusation of sexual impropriety a decade or so earlier (Plut. Crass. 1.2$).{ }^{10}$ Even Cicero's own wife Terentia was able to take refuge in the precinct of the Vestals (Atrium Vestae) with her half-sister, the Vestal Fabia, during her husband's exile in 58 BC (Fam. 14.2.2). ${ }^{11}$

\footnotetext{
${ }^{9}$ Wildfang 2006: 98, Broughton 1952: 172, Rüpke 2005: 1103 no. 2218.

${ }^{10}$ Ward 1977: 188n.52, Bauman 1992: 61, Scardigli 2003: 102, Cadoux 2005: 166-68, Broughton 1952: 114.

${ }^{11}$ Cf. Plut. Cat. Min. 19.3, Ascon. 91 Clark; Bauman 1992: 63, Rüpke 2005: 1577.
} 
In some cases, the benefits these priestesses provided to the social and political prestige of their families extended beyond their own deaths. Although they were unable to produce descendants in the truest sense of the term, certain Vestals were given pride of place in the honor rolls of ancestors that were so important to the authority of noble Roman households. The exemplum of Aemilia, whose innocence in the face of a wrongful accusation for unchastity (incestum) was proved by the miraculous rekindling of the fire on Vesta's hearth, was cherished by succeeding members of her gens. ${ }^{12} \mathrm{~A}$ sestertius minted under the authority of M. Aemilius Lepidus in $61 \mathrm{BC}$ displays the portrait of a Vestal, no doubt a reference to the virtue of this famous kinswoman [figure 1]. ${ }^{13}$ Claudia's intervention on behalf of her triumphing father was similarly commemorated by one of her "descendants," the moneyer C. Clodius Vestalis, in 41 BC. ${ }^{14}$ Her story also features prominently in the family history of the patrician Claudii that begins Suetonius' biography of the emperor Tiberius (Tib. 2.4), and Cicero invokes her memory in his discussion of the famous ancestors whose legacy had been besmirched by the adulterous Clodia (Cael. 34). ${ }^{15}$

As the context of the last reference makes clear, attacks on the moral integrity of women were a time-honored means of carrying forward one's enmity against male family

\footnotetext{
${ }^{12}$ Dion. Hal. $A R$ 2.68.3-4, Val. Max. 1.1.7, Prop. 4.11.53-54.

${ }^{13}$ Crawford 1974: 444 no. 419, Hallett 1984: 88-89, Flower 1996: 85.

${ }^{14}$ Crawford 1974: 521 no. 512.

${ }^{15}$ Cicero also mentions Claudia Quinta, who was also, in some versions of the tradition, remembered as a Vestal virgin: Sen. fr. 80 Haase; Scheid 2001.
} 
members in Roman public life. Prosopographers have been accordingly attentive to the role that factionalism may have played in the accusations of sexual impropriety that were periodically leveled against individual Vestals. The most closely scrutinized case involved charges against three Vestals — an Aemilia, a Licinia, and a Marcia— two of whom were initially exonerated in their trial before the pontifices in $114 \mathrm{BC} .{ }^{16}$ This verdict led to public outrage, and the following year the popular assembly passed a law calling for the Vestals to be retried before a specially established tribunal, presided over by the grim L. Cassius Longinus Ravilla, which inevitably found all three guilty of incestum. Although scholarly consensus about the nature of the political motivations at work in this drama is lacking, it seems clear that the people's repudiation of the pontifical inquiry reflected a reasonable suspicion that the priestesses had been shielded by their noble family connections. ${ }^{17}$

${ }^{16}$ Plut. Mor. 284A-C and Orosius 5.15.20-22 give the fullest accounts. Other sources in Broughton 1951: 536-37, Rüpke 2005: 734 no. 491, 1103 no. 2219, 1134 no. 2361. On the jurisdiction of the pontifices in trials for incestum, see Cornell 1981: 29-30, Lovisi 1998: 715-19.

${ }^{17}$ Ascon. 45-46 Clark. See Münzer 1920: 240-44 (=1999: 222-24), Gruen 1968a, 1968b: 127-31, Bauman 1992: 53-58, McDougall 1992, Martini 2004: 188-98. Gruen's analysis veers into difficulty when he speculates that one of the male defendants in the case, identified by Plutarch (Mor. 284b) as Boutétıos Bápßapos (or Báppos), was somehow complicit with the aims of the prosecution (1968b: 130 "political opposition to the Metellan factio is suggested in both instances"). Whatever damaging evidence this man's 
It is also apparent that families felt obliged to defend their Vestal kin when such charges were leveled against them. One of the earliest recorded speeches of the orator L. Licinius Crassus was his eloquent, though unsuccessful, defense of the Licinia condemned in 113 (Cic. Brut. 160). As Cicero was running for the consulship against Catiline in 64 , he had to walk a very fine line when referring to his opponent's trial for incestum a decade earlier, because the Vestal in question was Cicero's own sister-in-law Fabia. The most he allowed himself to say was that Catiline's manner of living was so vile "that there is no place so holy that your approach does not suggest a crime, even when no fault resides therein" (cum ita vixisti ut non esset locus tam sanctus quo non adventus tuus, etiam cum culpa nulla subesset, crimen afferret, Tog. Cand., ap. Ascon. 91 Clark). ${ }^{18}$

Taken together, this evidence suggests that, within the competitive ethos of the Roman aristocracy during the late Republic, a Vestal virgin represented an asset of considerable value for promoting the social and political prestige of her family. Insofar as these venerable priestesses were still bound to the interests of their families of origin, it is slave provided in the case, it could only have resulted in his master's death if convincing (see below, Section IV.B). Cf. the quaestor M. Antonius, who was exonerated on the basis of a loyal slave's testimony in the case: Val. Max. 6.8.1.

${ }^{18}$ Cf. Sall. Cat. 15.1; Epstein 1986: 232-33, Bauman 1992: 61. It should be noted that Cicero does not seem to have benefitted too much from his wife's relationship with this Vestal. Treggiari 2007: 31 notes the absence of direct references to Fabia in his published correspondence. 
easy to see why prominent patrician gentes like the Claudii and the Aemilii were willing to commit their daughters to service as Vestals, rather than giving them in marriage, as other women were often deployed, to secure precious political and economic alliances. ${ }^{19}$ It is only with the arrival of Augustus, and his monopoly on the apparatus of state power, that we hear of difficulties in attaining a full complement of candidates for the lottery in which new priestesses were chosen. The first time this happened, Augustus is said to have reproached the nobles for their lack of civic-mindedness by insisting that he would have offered up his own granddaughters if only they were of an eligible age (Suet. Aug. 31.3). Later in Augustus' reign, a law was passed that opened up the selection process to the daughters of freedmen, a social class that remained eager for any opportunity of social advancement (Dio 55.2.5). ${ }^{20}$ Ultimately, as Gellius reports (1.12.12), the procedure was to forego the selection of Vestals by lot and have the emperor as pontifex maximus pick out a girl of respectable parentage directly.

\section{B. THE PRINCIPATE}

${ }^{19}$ Kroppenberg 2010: 427, cf. Hopkins 1983: 86-88, Treggiari 1991: 107-19, also Rubin 1975: 171-77.

${ }^{20}$ Mekacher 2006: 25, Mekacher and Van Haeperen 2003: 77-78. On the chronology of these changes, Guizzi 1968: 69-71, Mekacher 2006: 106. Rüpke 2012: 191-92 notes the proliferation of plebeian Vestals in the last century BC, but construes this shift (unnecessarily, in my view) as evidence for patrician avoidance of the priesthood. 
With the advent of the Principate, our evidence for the lives of individual Vestals expands to include epigraphic testimony. ${ }^{21}$ Not only do these records increase the number of Vestals we know by name, but they also give a more direct, though still fragmentary, account of the attachments that these priestesses publicly maintained with the other members of their families. An inscription from Athens commemorates the praise that the people of that city bestowed upon "Aurelia, virgin priestess, daughter of Cotta, on

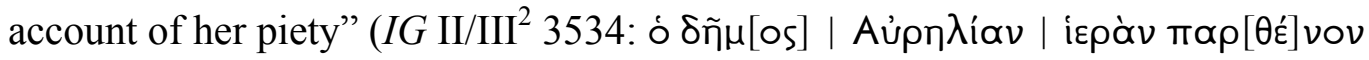

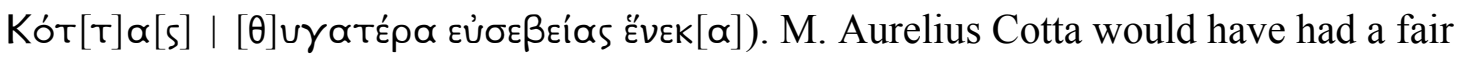
amount of interaction with the Athenians in his role as proconsul of Asia in AD 35/6. ${ }^{22}$ It is likely, therefore, that honors for this Vestal were granted with an eye to the sensibilities of her influential father. Something similar could be said of an otherwise verbatim dedication to "Vibidia, the daughter of Sextus Vibidius Virro" (IG II/III ${ }^{2} 3532$ ). Although we are not so well informed about the contours of Virro's career, he was honored elsewhere by the Athenians for his virtue and goodwill toward them $\left(I G \mathrm{II} / \mathrm{III}{ }^{2} 4161\right) .{ }^{23}$ If these were the only dedications of their type, one might be tempted to dismiss such nomenclature as demonstrating nothing more than the normal patronymic conventions of Greek and Latin epigraphy. But fathers are not the only family members to receive

${ }^{21}$ On the lack of epigraphic evidence from the Republic, see Schultz 2006: 49, 70-71. ${ }^{22}$ PIR $^{2}$ A 1488, FOS 131, Palmer 1971, Syme 1986: 236-39, Rüpke 2005: 795 no. 793. ${ }^{23}$ PIR ${ }^{1}$ V 373, FOS 805, Syme 1949: 17, Rüpke 2005: 1367 no. 3485. A third Athenian inscription $\left(I G \mathrm{III}^{2} 3533\right)$ honors the Vestal Valeria, with no indication of her parentage (FOS 769, Rüpke 2005: 1343 no. 3364). 
mention in this context. The people of Tenos also set up an honor for "Junia Torquata, the sister of C. Junius Silanus" (CIG XII 5, 920). This brother, of course, was proconsul of Asia in $20 / 21 .{ }^{24}$ Insofar as the priestesses' duties at the hearth of Vesta prevented them from leaving Rome for any extended period, it is safe to conclude that the male relatives named in these inscriptions were far more likely to see what these Greek cities had done in their honor.

The parentage of Junia Torquata is also commemorated in two dedications set up in Rome:

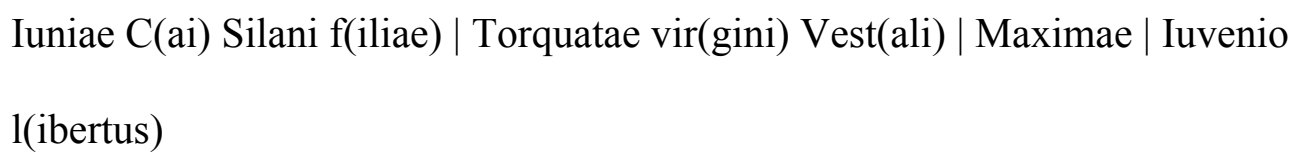

CIL VI 2127

For Junia Torquata, daughter of Gaius Silanus, chief Vestal virgin, from her freedman Juvenio.

Iunoni | Iuniae C(ai) Silani f(iliae) | Torquatae | sacerdoti Vestali | annis LXIIII || caelesti patronae | Actius 1(ibertus)

CIL VI 2128

${ }^{24}$ PIR ${ }^{2}$ I 825, FOS 475, Rüpke 2005: 1078 no. 2102. 
To Juno, for Iunia Torquata, daughter of Gaius Silanus, Vestal priestess, aged 64 years, heavenly patroness, from her freedman Actius.

Even as the terms used to describe Torquata's priestly office varies, the insistent recording of filiation suggests that, at least in certain circumstances, Vestals continued to link their identities (and to have them linked) with that of their fathers. Given the likelihood that her father was already dead when these inscriptions were carved, this specification is probably more revealing of the Vestal's own preferences. ${ }^{25}$ Even more noteworthy in this regard is the designation of a later Vestalis maxima as "Praetextata, the daughter of Crassus" in an inscription from the reign of Trajan (CIL VI $32409=I L S$ 4924). The parent in question, M. Licinius Crassus Frugi, had been condemned under Nero. ${ }^{26}$

Vestals were by no means unique among the women of the early Principate in their propensity to advertise their filiation. ${ }^{27}$ What was different about the Vestals, however, was their unique social position. Even as political realities were dramatically reconfigured by the emperors, the Vestal virgins continued to possess considerable

${ }^{25}$ PIR ${ }^{2}$ I 824, Syme 1986: 193. Junia's father is not mentioned when her name is used on the tombstones of her freedmen (CIL VI 20788, 20852).

${ }^{26}$ Plin. Ep. 1.5.3; PIR² L 191, FOS 495, Rüpke 2005: 1103 no. 2220.

${ }^{27}$ Hallett 1984: 54-59, 77-110. Cf., e.g., CIL VI $1274=$ ILS 881: Caeciliae $\mid$ Q. Cretici f(iliae) $\mid$ Metellae Crassi, CIL VI 1445 = ILS 956: Dis $\mid$ Manibus $\mid$ Liciniae Crassi $\mid$ Frugi pontificis f(iliae) $\mid$ Magnae | L. Pisonis pontificis uxori. 
personal authority, which they might be expected to use on behalf of friends and family. When Iunia Torquata's brother C. Silanus was condemned following his proconsulship of Asia, she successfully petitioned Tiberius to let him live out his exile on Delos, rather than in the gloomy isolation of Gyarus (Tac. Ann. 3.69.6). ${ }^{28}$ She may also have had a hand in the return of D. Silanus, who had been exiled for some involvement in the scandals of Augustus' daughter Julia, although Tacitus attributes his restoration solely to the influence (and eloquence) of their other brother, M. Silanus (Ann. 3.24.3). ${ }^{29}$ On the other hand, Vibidia was apparently unable to do anything to prevent Tiberius from expelling her father from the senate for squandering his fortune (Ann. 2.48.3). Praetextata was likewise powerless to avert the destruction of her father under Nero, although she would join her widowed mother and siblings at the start of Vespasian's reign in an unsuccessful bid to get the senate to condemn Crassus's accuser for prosecutorial misconduct (Tac. Hist. 4.42.1). ${ }^{30}$

The importance of such appeals by individual Vestals lies not in their success or failure, however, so much as in the fact that they happened at all. In his account of the trial of Torquata's brother C. Silanus, Tacitus notes that those closest to the accused did not come to his aid lest they attract an accusation of treason themselves (et ne quis necessariorum iuvaret periclitantem maiestatis crimina subdebantur, vinclum et

${ }^{28}$ Mekacher 2006: 105, Scardigli 2003: 104.

${ }^{29} P I R^{2}$ I 826, Syme 1986: 193-95.

${ }^{30} \mathrm{Cf}$. Plin. Ep. 1.5.3. Tacitus does not mention the daughter's status as a Vestal in his account of the appeal. 
necessitas silendi, Ann. 3.67.3). This revealing comment puts the unique nature of the Vestals' position in stark relief. Because of the sanctity derived from their indispensable role in state cult, these priestesses were largely immune to the dangers of Imperial politics. They could maintain their ties with family and friends, and even speak out on their behalf, without having to calculate the political risks. No wonder, then, that after Messalina's downfall the only person to plead with Claudius on her behalf was the aged Vibidia (Tac. Ann. 11.34.2). ${ }^{31}$

It is in this light that we should approach the case of Junia, a Vestal from the age of Pliny the Younger, who was cared for by her in-law (affinis) Fannia when she became ill (Plin. Ep. 7.19.1). ${ }^{32}$ Because Fannia was not agnatic kin, and because her role as Junia's nurse was confirmed by pontifical authority (ibid.), this case has been misconstrued as evidence for a severing of ties between Vestals and their families. ${ }^{33} \mathrm{In}$ fact, it is clear that Fannia's affinitas with Junia is likely to have passed through one of the spiritual adherents of her father, the famous dissident Thrasea Paetus, just as Fannia herself had been married to the noted troublemaker Helvidius Priscus. ${ }^{34}$ The Vestal's father (or, less likely, her brother) was either Thrasea's biographer Q. Arulenus Junius Rusticus, who was put to death under Domitian, or Junius Mauricus, who was exiled at the same time (Plin. Ep. 3.11.3)—whichever one, the marriage link with Thrasea's family

\footnotetext{
${ }^{31}$ Bauman 1992: 176-77.

${ }^{32} P I R^{2}$ I 852, FOS 466, Rüpke 2005: 1078: 2101.

${ }^{33}$ Beard 1980: 21, Staples 1998: 143.

${ }^{34}$ PIR $^{2}$ F 118, H 59, FOS 259.
} 
likely played a role in his condemnation. ${ }^{35}$ As a consequence, Fannia would have been, in all likelihood, the closest living relative that Junia had left.

A Vestal's social prestige could have more mundane implications for her role in the family as well. An epitaph set up by Cossus Cornelius Gaetulicus for his concubine Eon refers to a grant of permission by his daughter, the Vestal Cornelia (CIL VI 17170: permissu Corneliae | Cossi Gaetulici fil(iae) v(irginis) V(estalis)). ${ }^{36}$ Whether this comment implies a sanction for the relationship or merely for the memorial, the mention of Cornelia's position as a Vestal seems to justify a display of solicitude for the opinion of a daughter that far exceeds what we would typically expect to find within the framework of a patriarchal Roman family.

\section{VIRGINES VESTALES MAXIMAE IN THE THIRD CENTURY AD}

Further evidence for the privileged place of the Vestal virgins, both within their families and in Roman society at large, can be found in the series of inscribed bases for the statues of the chief Vestals (virgines Vestales maximae) that were set up in and around the sacred precinct of the Atrium Vestae, where the priestesses lived and performed most of their sacred duties. ${ }^{37}$ The surviving inscriptions, which date almost

${ }^{35}$ PIR I 771, 730, Syme 1991: 582-83.

${ }^{36}$ PIR ${ }^{2}$ C 1392, FOS 274, Rüpke 2005: 905 no. 1300, Mekacher 2006: 107.

${ }^{37}$ CIL VI 2131-45, 32403-28, ILS 4924-38; Nock 1930 (appendix). See Frei-Stolba 1998: 233-34, 239-41, Mekacher 2006: 121-48, 200-209, LTUR I 138-42 [R. T. Scott]. 
entirely from the third century, provide a wealth of information about the Vestals' social position in the later Imperial period. Not only do they record the names of the donor and the honored virgo Vestalis maxima, they also often indicate the nature of the relationship between the two. In some cases, the inscription even specifies a reason for the dedication.

Siblings and other family members feature prominently among the sponsors of these monuments. Q. Lollianus Plautius Avitus, who was an augur and consul under Septimius Severus, set one up for his "most holy sister," the chief Vestal Terentia Flavola $(C I L$ VI $32412=$ ILS 1155: sorori sanctissimae $) .{ }^{38}$ The inscription details Lollianus' full cursus honorum and includes his wife Claudia Sestia Cocceia Severiana and daughter Lolliana Plautia Sestia Servilla as joining him in the dedication. Flavola's other brother, Terentius Gentianus, who identifies himself as "flamen Dialis, senator (vir clarissimus), and praetor tutelaris," also dedicated a statue for this sister, including his own wife Pomponia Paetina and his brother's son Lollianus Gentianus as named donors as well $(C I L$ VI $2144=I L S 4927) .{ }^{39}$ It seems clear that the purpose of inscriptions like these was not just to glorify the chief Vestal who received a statue, but also to tout the importance of the relationship that existed between the honorand and the people making the dedication. Both parties benefited from the transaction. ${ }^{40}$ In setting up these monuments to their sister, the brothers were able to raise their own profiles by advertising their

${ }^{38}$ PIR $^{2}$ H 36, 44, FOS 411, Rüpke 2005: 1026 no. 1869, 1315 no 3219.

${ }^{39}$ PIR ${ }^{2}$ H 37, 35, Rüpke 2005: 1316-17 no. 3228. See Mekacher 2006: 111 on the dating of these inscriptions.

${ }^{40}$ Cf. Eck 2010. 
accomplishments in the heart of the Roman Forum. Flavola's prestige would also have increased by being linked to that of her brothers, both of whom held high office and prominent priesthoods in their own right. The inclusion of the names of the brothers' wives and children further suggests that these inscriptions served as a public vehicle with which to reaffirm both the solidarity of the family as a unit and the integral position of the chief Vestal within it.

When family members were not responsible for a dedication, more effort was deployed in explaining the reason for the donor's generosity. In some cases, we are able to glimpse the more prosaic advantages that might be won through the influence of a highly-placed Vestal. ${ }^{41}$ Assistance in securing status and position is acknowledged in a dedication from 240:

Campiae Severinae $\mid$ v(irgini) V(estali) $\max ($ imae $) \mid$ sanctissimae benignissimae $\mid$ pro conlatis in se beneficiis | equestr(is) ord(inis) item secundae militiae || Aemilius Pardalas trib(unus) coh(ortis) I | Aquitanicae petito eius ornatus

$$
C I L \text { VI } 2131=I L S 4929
$$

To the most holy and kind Campia Severina, chief Vestal virgin, from Aemilius Pardalas, tribune of the first Aquitanican cohort, honored through her entreaties, in return for the benefits conferred on him: equestrian status and a second military posting.

${ }^{41}$ Frei-Stolba 1998: 246-47. 
Severina is also honored by a certain Q. Veturius Callistratus for her help in securing a procuratorial post in the administration of the imperial library and for her "unblemished and proven chastity [which] the senate publicly heaps with unceasing praise" (CIL VI 2132 = ILS 4928: cuius sinceram pudicitiam | senatus comprobatam aeterna | laude publice cumulavit). ${ }^{42}$

References to specific benefactions of this sort are rare, however. More often, the dedicatee's sanctity and religious scruples are cited as sufficient justification for the honor. An inscription set up in 286 is typical:

Coeliae Claudianae | v(irgini) V(estali) maximae | sanctissim(ae) ac super omnes $\mid$ retro maximas religiosissimae | cuius sanctimonia a cunctis praedicatur $\mid$ nunc certe pertinet esse te talem cuius | laudem numen quoque Vestae honoravit. | Fl(avius) Eucharistus Septim(ius) Epictetus i(uvenis) p(erfectissimus) $\mid$ Aur(elius) Optatus sacerdotes sacrae $u[\mathrm{rb}]$ is $\mid$ de $X$ prim(is)

CIL VI $2137=I L S 4936$

For the chief Vestal Coelia Claudiana, the most sacred and above all previous chief Vestals the most dutiful, whose sanctity is declared by all. Now indeed it matters that you are the kind [of priestess] whose praise has been bestowed by the spirit of Vesta herself. From Flavius Eucharistus, Septimius Epictetus, a youth of

${ }^{42} P I R^{2}$ C 379, Rüpke 2005: 856 no. 1076. 
high equestrian status, and Aurelius Optatus, priests of the holy City from the ranks of the first ten.

Without knowing more about the circumstances of this dedication, we can only say that its language is what we might expect priests to use when praising one of their own. ${ }^{43}$ Coelia was honored in similar terms by her fellow Vestal Octavia Honorata, who claims to have been "carried constantly forward by her (sc. Coelia's) divine advice" (CIL VI 2138: divinis | eius admonitionibus semper provecta). ${ }^{44}$

Further emphasis on the role of the numen Vestae in approving a priestess's merits can be found in the sentiments of one of Coelia's sisters, who set up the following: ${ }^{45}$

Coeliae Claudianae | v(irgini) V(estali) maximae $\mid$ a diis electa $<$ e $>$ merito $\mid$ sibi talem antistitem | numen Vestae reservare || voluit | Coelia Nerviana soror una | cum Pierio coniuge ac liberis | suis orantes ut per tot saecula | facere dii permittant CIL VI $2139=I L S 4935$

\footnotetext{
${ }^{43}$ Frei-Stolba 1998: 244-45. Cf. CIL VI 2136, set up a few days earlier by unnamed sacerdotes sacrae urbis.

${ }^{44} P I R^{2}$ C 1250, Rüpke 2005: 901 no. 1281,1178 no. 2556.

${ }^{45}$ On this theme more generally, see Nock 1930, Frei-Stolba 1998: 242-44.
} 
For the chief Vestal Coelia Claudiana, chosen by the gods through her merits, the kind [of priestess] whom the spirit of Vesta wished to keep as overseer of her rites. From her sister Coelia Nerviana, together with her husband Pierius and their children, who pray that the gods allow [her?] to do so for so many generations.

By celebrating the virtue and religious authority of their kinswomen, these family members lay their claim to some share of it. Similar sentiments are also expressed in an inscription set up in 247 :

Flaviae L(uci) fil(iae) | Publiciae v(irgini) V(estali) max(imae) | sanctissimae piissimaeq(ue) | cuius sanctissimam et | religiosam curam sacror(um) || quam per omnes gradus | sacerdotii laudabili admi|nistratione operatur numen | sanctissimae Vestae matris | comprobavit || Aemilia Rogatilla c(larissima) f(emina) sororis fil(ia) | cum Minucio Honorato Marcello | Aemiliano c(larissimo) p(uero) filio suo | ob eximiam eius erga se $\mid$ pietatem

$C I L$ VI $32414=I L S 4930$

For Flavia Publicia, daughter of Lucius, most sacred and pious chief Vestal, whose sanctity and dutiful concern for the rites that she has performed with praiseworthy conduct through all stages of the priesthood, the spirit of the most holy mother Vesta has confirmed. From Aemilia Rogatilla, of senatorial rank, her 
sister's daughter, with Minucius Honoratus Marcellus Aemilianus, a boy of senatorial rank, her son, on account of her extraordinary piety toward them.

The phrase ob eximiam eius erga se pietatem is the closest that any dedication by a family member comes to acknowledging a specific benefit conferred upon the dedicators by the honorand. There is no need to explain further how Flavia Publicia's pietas might have manifested itself for her niece and grandnephew. The fact of their kinship is sufficient to justify their role in the celebration of her virtues. ${ }^{46}$

That none of these inscriptions records a dedication by a parent to a chief Vestal can be explained by the realities of Roman demography. The title of virgo Vestalis maxima seems to have gone to the longest serving member of the priesthood, so it is unlikely that one's parents would have lived long enough to see her reach this position. ${ }^{47}$ There is, however, one set of parents who managed to insinuate their own connection to a more junior member of the college into their praise of Flavia Publicia: ${ }^{48}$

Fl(aviae) Publiciae v(irgini) V(estali) $\max ($ imae) $\mid$ merito sanctissimae ac piissi|mae quae rite et pervigili adminis|tratione omnes gradus laude $\mid$ cumulata sacra sua venerata vi||vit ut saeculari aetate ministerio | adsit et in futoro perseveret | Q(uintus) Terentius Rufus et Caenia | Verissima parentes | Terentiae

${ }^{46} P_{I R}^{2}$ A 426, F 438, Rüpke 2005: 985 no. 1652.

${ }^{47}$ Mekacher 2006: 39, cf. Ov. Fast. 4.639; Saller 1987.

${ }^{48} P_{I R}^{2}$ C 147, T 83, 107, Rüpke 2005: 1315 no. 3220. 
Rufillae v(irginis) V(estalis) || cuius multi temporis bonitatem | et humanitatem eius circa se | in brevi senserunt

$C I L$ VI $2135=I L S 4934$

For Flavia Publicia, by deserts the most sacred and pious chief Vestal, who lived solemnly and conducted her vigil through all stages [of the priesthood] as her own sacred praise grew and was revered, such that her presence is felt in this age through her works and will persist in the future. From Q. Terentius Rufus and Caenia Verissima, parents of the Vestal virgin Terentia Rufilla. They briefly experienced the goodness of her great period [of service] and her human feeling toward them.

If taken at face value, the language used in this inscription suggests that, rather than representing the removal of a daughter from her family, entry into the Atrium Vestae brought one's family into closer contact with the other members of the priesthood. While this new arrangement may have involved some alteration of the internal dynamics of the family, it does not on any measure require a severing of family ties. Once again, the prestige of the daughter's position only intensified the importance of the connection she maintained with the family of her birth.

III. “CAPTURED” VESTALS: KINSHIP, GENDER, AND PRIESTLY STATUS 


\section{A. THE EVIDENCE OF GELLIUS}

The materials discussed up to this point suggest that, over the course of four centuries, the Vestal virgins were able to maintain more or less vibrant, reciprocal relationships with the other members of their families. Even as political and cultural changes in Roman society altered the implications of these ties, there is nothing in this evidence to suggest that the bond between Vestals and their agnatic kin diminished in importance. Nevertheless, a strand has emerged in the scholarship relating to the Vestals' position vis-à-vis the normative patterns of Roman kinship that seeks to prioritize the testimony of a single source - a chapter on the "capture" of new Vestal virgins in the miscellany compiled by the lawyer and polymath Aulus Gellius in the middle of the second century AD (Gell. NA 1.12). ${ }^{49}$ This piece of antiquarian discourse has been so thoroughly dissected by scholars that the conclusions for which it has been marshaled as evidence sometimes stand in stark contrast to the impression one forms when reading it through for the first time. This is to be expected, perhaps, and we should not insist that Gellius' terms of analysis or his underlying assumptions about Roman culture determine our own. It nevertheless will be worth taking another look at what Gellius has to say in order to see how his evidence might be reconciled with the individual cases assembled in the preceding section.

Gellius begins his discussion of the "capture" of a Vestal virgin (de virgine capienda) by invoking the Augustan-era jurisprudent Antistius Labeo, whom he

${ }^{49}$ See above, n.3, and below, section IV. 
describes as the most meticulous of those who had previously written on the topic. ${ }^{50}$ From this wellspring of authority Gellius adduces the basic requirements that a girl must fulfill if she is to be selected as a Vestal: she must be between the ages of six and ten, have both parents alive, be free of physical disabilities (particularly in her speech and hearing), and not have undergone emancipation from her father's control (1.12.1-4). Additionally, her father cannot have undergone emancipation, and neither parent can have been a slave or have engaged in a degrading occupation (1.12.4-5). Exemptions for girls whose sisters were already Vestals, whose fathers held certain priesthoods, and girls who were betrothed to a pontifex are also discussed (1.12.6-7). Finally, there is a requirement that the girl's parents must reside in Italy and an exemption for the daughters of those who have borne three children; Gellius cites Labeo's contemporary and rival Ateius Capito for these last two details $(1.12 .8) .^{51}$

This list of prerequisites and exemptions, which largely center on the status of the girl's parents, does little to dispel the impression that a Vestal's family should form an important part of her identity. If anything, the requirement that the candidate be patrima et matrima would seem to ensure that she would have a family with which to share her fortunes as she entered into the priesthood. Following Beard (1980), however, the focus of certain scholars has shifted decisively onto the next part of Gellius' discussion:

\footnotetext{
${ }^{50}$ NA 1.12.1: quorum diligentissime scripsit. (= De iure ponteficio fr. 3 Bremer). On Labeo's reputation, see Tac. Ann. 3.75.1, Gell. NA 13.10.1-3, Dig. (Pomp.) 1.2.2.47. ${ }^{51}$ De iure ponteficio fr. 7 Bremer.
} 
Virgo autem Vestalis simul est capta atque in atrium Vestae deducta et pontificibus tradita est, eo statim tempore sine emancipatione ac sine capitis minutione e patris potestate exit et ius testamenti faciundi adipiscitur.

Gell. NA 1.12.9

Moreover, as soon as a Vestal virgin is taken and led into the house of Vesta and handed over to the pontifices, at that very moment, without emancipation or a loss of status, she leaves her father's authority and acquires the right to make a will.

For some scholars, at least, this immediate severing of the father's potestas over a captured Vestal, together with other peculiarities about her legal position, have come to be regarded as the defining features of her kinship status. While I do not intend to deny that the nature of the Vestals' place in Roman society was extraordinary, I do want to make two observations about the way this evidence has been used by those who would emphasize the priestesses' isolation from their families.

The first difficulty arises from the source bias (partly acknowledged by Beard 1995: 171-72) of those scholars who, in their efforts to decode the underlying principles of Roman culture, have tended to privilege the works of ancient legal and antiquarian writers in their analysis. Insofar as these authorities deal in generalizations and fixed rules, it is tempting to regard the insights they provide as uniquely revelatory, while dismissing the importance of the (necessarily messy and ambiguous) contextual evidence of individual cases like those examined in the previous section. Acknowledging the 
devotion of Claudia and Fonteia to their male kin, Ariadne Staples concedes that "a legal rule did not necessarily undermine affective ties nor the acknowledgement of those ties" (1998: 144). She nevertheless proceeds to anoint the legal rule as her preferred guide to the underlying "cultural ideology" that governed the Vestal's position within her family. $^{52}$

In my view, this is a problematic methodological distinction. The interventions and monuments discussed in the preceding section are not simply inconsequential or perverse expressions of emotion by Vestals who did not fully appreciate the cultural significance of their social position. They are instead, I argue, genuine manifestations of social bonds that served to constitute, in part, the priestesses' place in Roman culture. Even if one could accept so narrow a definition of these cases as evidence for the persistence of "affective ties" alone, it would still be necessary to account for the continued existence of such ties. Love is as much a construct of cultural ideology as the law, after all. ${ }^{53}$ The social dynamics involved in a Vestal's continued commitment to the

${ }^{52}$ Staples 1998: 144: "Social practice might on occasion mask the ideal, but it does not invalidate it.” Cf. Parker 2004: 573n.42, Kroppenberg 2010: 435. Beard 1980 ignores these cases altogether, but critiques her own approach in a later reconsideration (1995: 171-73).

${ }^{53}$ Evans-Pritchard 1965: 47, Tarlow 1999. For the Roman context, see Saller and Shaw 1984: 134-38, Shaw 1991, esp. 66-68, Dixon 1991, Thomas 1992: 86-87, Kaster 2005: 119-20, also Veyne 1978, Foucault 1986: 72-95. 
fortunes of her agnatic kin (and vice versa) thus should not be dismissed as less meaningful than the privileges and procedures that established her legal independence.

Overreliance on Gellius and similar sources has led to interpretations of these legal rules that stand in isolation not just from the lived experience of known Vestals, but also from that of other women in Roman society. As Gellius' own references to emancipation and a loss of status (capitis deminutio) suggest, there were other ways for girls and women to obtain release from the potestas of their fathers. Such events being relatively more common than "capture" into a priesthood, the legal scholar takes note of their absence in the Vestals' case. Other events that brought an end to patria potestas, including forms of marriage such as coemptio and the (inevitable) death of a paterfamilias, are not mentioned, presumably because these circumstances were obviously precluded by the case at hand. ${ }^{54}$ As a legal matter, therefore, the severing of patria potestas was not in itself an extraordinary event. What Gellius, following Labeo, finds more interesting is the Vestals' ability to make a will. The reasons for this change are more complex, as we shall see, but they relate only superficially to the Vestals' kinship status.

The second, related error that must be avoided when dealing with these sources is the tendency to de-historicize these legal arrangements, such that the rules associated with a Vestal's "capture" come to be regarded as some kind of catechism of fixed principles that reflect enduring truths about the nature of Roman culture and religion. In fact, Gellius' account makes it abundantly clear that the religious procedures associated

\footnotetext{
${ }^{54}$ See further Crook 1967: 113, Watson 1971a: 33.
} 
with the capture of a new Vestal virgin were contingent upon changing historical circumstances. Both of the items he preserves from Capito suggest an evolution of the rules of eligibility (insofar as a citizen residing outside of Italy would have been inconceivable before the second Punic war and the exemption for families with three children reflects a legal category created as part of Augustus' legislation). ${ }^{55}$ Gellius also goes on to discuss the terms of a lex Papia, a law of uncertain date that established (and therefore presumably changed) the procedure for selection, which required that new Vestals be chosen by lot from a slate of twenty candidates (1.12.11). ${ }^{56}$ This law itself had been rendered obsolete in Gellius' day, when it was customary for the senate to grant the pontifex maximus (i.e., the emperor) an exemption from its terms once a suitable candidate had been identified (1.12.12).

Both the context and the historically contingent nature of this legal framework have important implications for how we evaluate the significance of what Labeo had to say about the Vestals' testamentary capacity. Near the end of this chapter, Gellius quotes from Labeo's commentary on the Twelve Tables:

Virgo Vestalis neque heres est cuiquam intestato, neque intestatae quisquam, sed bona eius $<$ in $>$ publicum redigi aiunt. Id quo iure fiat, quaeritur.

\footnotetext{
${ }^{55}$ Mekacher and van Haeperen 2003: 67-68.

${ }^{56}$ Mekacher and van Haeperen 2003: 69-72 offer the most likely account. See also Guizzi 1968: 68-86, Saquete 2000: 127-31, Rüpke 2005: 1579-84.
} 
Gell. $N A 1.12 .18^{57}$

A Vestal virgin is not the heir to any intestate person, nor is anyone her heir when she is intestate, but they say her property returns to the public (coffers). By what rule this happens is disputed.

We can assume that the controversy about id quo iure fiat was limited to the basis for the escheatment of an intestate Vestal's property to the state, because the reasoning of the first part of this statement is clear enough. ${ }^{58}$ Under the terms of the Twelve Tables, a daughter who left the potestas of her father typically forfeited her claim as a legitimate heir (sua heres) as well as any agnatic claim on the property of a brother. ${ }^{59}$ The Tables did not provide for intestate succession among cognates, although this was subsequently permitted under the terms of the praetor's edict. Assuming the Vestals' position was not affected by the change, the resulting anomaly may have been the source of Labeo's confusion. $^{60}$

${ }^{57}$ Ad XII tabulas libri fr. 2 Bremer, cf. Riccobono 1941: 37 (Tab. V.1), Crawford 1996: 634.

${ }^{58}$ Guizzi 1968: 165-67, Gardner 1986: 23.

${ }^{59}$ Gai. Inst. 3.2, 14, 19-21; Düll 1953: 384, Crook 1967: 119, Watson 1971b: 176-77. ${ }^{60}$ Gai. Inst.3.24-25; Watson 1971b: 178-83, Saller 1994: 165. Rules relating to the legal status of priests were uniquely resistant to modernization: cf. Tac. Ann. 4.16. 
What is more remarkable about the Vestals' situation, however, is the possibility that they should become anything but intestate in the first place. Before the time of Hadrian, women who had not undergone some form of capitis deminutio were not allowed to make wills. ${ }^{61}$ But Gellius, following Labeo, has already made it clear that the Vestals did not undergo this change of legal status when they were "captured" into their priesthood (1.12.9). Gellius neglects to mention another complicating factor here, which must have interested Labeo. Ordinarily, the women who were allowed to make wills still required the consent of a male guardian, or tutor, just as they would in conducting any other legal transaction. ${ }^{62}$ But the jurist Gaius, who wrote around the same time as Gellius, records that the Twelve Tables explicitly exempted the Vestal virgins from the tutela that was required for minors, the mentally incapacitated, and all other women who were sui iuris (Inst. 1.145). The Vestals' ability to make a will thus seems to have been part of a broader set of legal rights, enshrined in the Twelve Tables, which allowed them to conduct business in their own name. ${ }^{63}$

Drawing on the theory that tutela originated as an effort by male agnates to maintain control over a family's property, some scholars have suggested that the Vestals' exemption from guardianship had something to do with their exclusion from the Roman

${ }^{61}$ Cic. Top. 4.18, cf. Gai. Inst. 1.115-115b; 2.112; Watson 1967: 152-54, 1971b: 22-23, Thomas 1992: 102.

${ }^{62}$ Gai. Inst.2.112, 118; see Watson 1971a: 35-41, Gardner 1986: 39-41, Thomas 1992: 131-32, also Saller 1994: 181-203.

${ }^{63}$ Guizzi 1968: 25-29, Kroppenberg 2010: 423, also Parker 2004: 573-74. 
family structure. ${ }^{64}$ However, the link between tutela and kinship was already somewhat attenuated by the time of the Twelve Tables, which allowed for the establishment of tutela by testament. ${ }^{65}$ This connection declined further with time, such that under the terms of a lex Claudia, agnates were explicitly barred from acting as tutores for their female relatives. ${ }^{66}$ In any event, if the goal was to cut Vestal virgins off from their families, a wholesale exemption from tutela would not be necessary. The same end could have been accomplished by the appointment of someone outside of the family-the pontifex maximus, for example—as their tutor.

That the Vestals' exemption from tutela had little to do with their kinship status is further indicated by the framework of the Augustan-era rules known as the lex Julia et Papia Poppaea, which among other things sought to promote the rearing of children by bestowing a suite of special legal privileges, known collectively as the ius liberorum, upon those who had given birth to an established number of children ${ }^{67}$ Chief among the

${ }^{64}$ Gardner 1986: 24-25, Staples 1998: 143, Parker 2004: 572-73, Wildfang 2006: 65, cf. Crook 1967: 113-14.

${ }^{65}$ Gai. Inst.1.155, Ulp. Tit. 11.14, cf. Riccobono 1941: 39 (Tab. V.6), Crawford 1996: 635-40; Watson 1971a: 25-26, Gardner 1986: 19, Saller 1994: 183.

${ }^{66}$ Gai. Inst.1.157, Ulp. Tit. 11.8.

${ }^{67}$ Astolfi 1970: 174-79, Dixon 1988: 88-91, Treggiari 1991: 66-80, Crawford 1996: 803. See, in general, Galinsky 1981, also Wallace-Hadrill 1981. The precise chronology of these innovations is uncertain: cf. Dio 53.13.2, 54.16.1. 
enticements for women to procreate was an exemption from tutela. ${ }^{68}$ Although it has rightly been noted that "Augustus' social legislation drove a coach and horses through the concept of tutela" (Gardner 1986: 20), we should not expect that a mark of status used to promote a conventional role for women within the family (i.e., motherhood) somehow conveyed an opposite meaning when applied to the Vestal virgins. In fact, the comparability of the Vestals' privileges and those of fertile matrons is confirmed by the fact that the Vestals, like the empress Livia Drusilla (who had only borne two sons), were granted the full ius liberorum by special dispensation. ${ }^{69}$ Insofar as this legislation reflects a stable set of cultural ideals, it suggests that the purpose of the older provisions was to set the Vestals apart from other women, but not necessarily from their families. ${ }^{70}$

\section{B. PRIESTLY PRIVILEGES}

Plutarch, who follows the Roman habit of attributing the bulk of the city's oldest religious traditions to Numa, includes the ability to make a will and the right to conduct



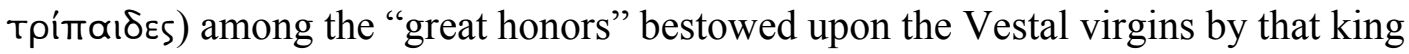

${ }^{68}$ Gai. Inst. 1.145, Arangio-Ruiz 1943: 71-73; Crook 1967: 115, Astolfi 1970: 71-72.

${ }^{69}$ Dio 55.2.6, 56.10.2; Mekacher and Van Haeperen 2003: 79, Guizzi 1968: 19, Purcell 1986: 85, cf. Beard 1980: 18.

${ }^{70}$ Pace Staples 1998: 145: “A contemporary legal artifice was thus used to maintain the Vestals' time honoured status.” 


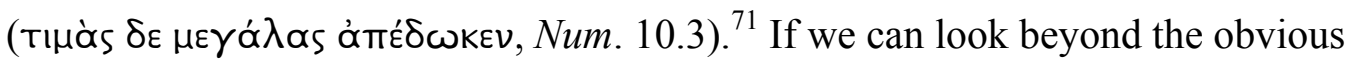
anachronism of this formulation, there is much to suggest the essential validity of Plutarch's characterization. Gaius also argues that the Vestals' longstanding freedom from tutela had originally been granted out of deference to their priesthood (in honorem sacerdotii, Inst. 1.145), and it is reasonable to think of the granting of these privileges to a girl upon her entry into the Atrium Vestae as an acknowledgement of the unique religious authority inherent in her priesthood. Before returning to the questions of what the "capture" of a Vestal was and what it was for, it will be useful to consider some of the other privileges enjoyed by these priestesses to see how they articulated a special position for the Vestal virgins within the Roman social order.

Another Vestal honor that Plutarch credits Numa with establishing is the privilege of being attended by lictors whenever they went out in public. ${ }^{72}$ The antiquity of this privilege is more uncertain, although it is possible that Cassius Dio is only referring to an increase in the scope of this protection when he records that each Vestal was granted her own lictor after one of them was inadvertently insulted while returning from a dinner party early in the reign of the second triumvirate $(47.19 .4) .{ }^{73}$ Whatever the timeframe, it is clear from Dio's account that the role of these lictors was to ensure that proper deference was shown to the Vestals' sacred authority. Going further, Beard has argued that this privilege, like the exemption from tutela, served to set the Vestals apart in

${ }^{71}$ Cf. Gell. NA 1.12.10, Liv. 1.20.2, Dion Hal. AR 2.64.5-66.1; Sacchi 2003: 321-26.

${ }^{72}$ Plut. Num. 10.3, cf. Sen. Contr. 1.2.3; Staples 1998: 145, Mekacher 2006: 29.

${ }^{73}$ Rüpke 2005: 1650. 
another way, by "invest[ing] the virgins with elements of a masculine status" (1980: 17). The point is well taken, insofar as all of the other officeholders to whom lictors were attached — magistrates with imperium and other priests within the pontifical collegewere men. ${ }^{74}$ This was true at least until the time of Augustus' death, when Livia seems to have been granted the services of a lictor when performing her duties as the priestess of her then deified husband. ${ }^{75}$ This additional exception to the all-male rule suggests that we should regard this privilege primarily as marking a distinction of status rather than of gender, however. After all, if the Vestals were unique among Roman women in being attended by lictors, magistrates and priests were also set apart from other men in the same way.

A less ambivalent privilege, which the Vestals clearly derived from their religious authority, was the right to be conveyed around Rome in a carriage. ${ }^{76}$ Among the restrictions on the use of carts (plaustra) set out in the so-called lex Iulia municipalis of the late first century $\mathrm{BC}$, there is a clause exempting the use of such vehicles by the Vestal virgins, the rex sacrorum, and the flamines for the performance of their religious duties, along with the use of these vehicles in triumphs and other public festivals (CIL I $2^{2} 593=I L S 6085,62-65:$ sacrorum publicorum p(opuli) $R$ (omani) caussa) ${ }^{77}$ A similar exemption had been included in the lex Oppia of 215 BC, a sumptuary law that among

\footnotetext{
${ }^{74}$ Purcell 1983: 148-51, 169, Van Haeperen 2002: 287-88, Latte 1960: 409.

${ }^{75}$ Dio 56.46.2; Purcell 1986: 90, Bauman 1992: 125.

${ }^{76}$ Mekacher 2006: 29-30.

${ }^{77}$ Riccobono 1941: 145-46.
} 
other things prohibited women from riding in a drawn vehicle "except for the sake of public rites" (nisi sacrorum publicorum causa, Liv. 34.1.3). ${ }^{78}$ Again, an exemption from restrictions placed on others marked the Vestals as unique, but the distinction was one of religious status, not gender. ${ }^{79}$ The gendered implications of riding in a cart through the city are uncertain at best: male priests and triumphing generals also enjoyed the privilege, but, once again, so did Livia and other women of the imperial house. ${ }^{80}$

The privilege of front-row seating at the games has already been mentioned, along with the political advantage that Fonteia's kinsman attempted to derive from it. In contrast to the exemption from tutela, this privilege was actually rendered more exclusive by Augustus' social legislation, as the lex Iulia theatralis, which introduced strict rules about where each class of person should sit, banished all women besides the Vestals to the highest rows of the amphitheater. ${ }^{81}$ The honor, once again, was about signifying status. Consistent with the Greek custom of prohedria, Roman magistrates also had special seats in the theater and at the games, as did certain male priests. ${ }^{82}$ In $24 \mathrm{AD}$, Livia was permitted to join the Vestals in these seats, although Tacitus records that this

${ }^{78}$ Cf. Val Max. 9.1.3, Crawford 1996: 382.

${ }^{79}$ Purcell 1986: 86, cf. McGinn 1998a: 245-47.

${ }^{80}$ Dio 60.22.2, cf. Suet. Cal. 15.1; Lucchi 1968.

${ }^{81}$ Suet. Aug. 44.2-3: women had previously watched the games promiscue; Rawson 1987: 85 .

${ }^{82}$ Tac. Ann. 16.12 .1 (viatores tribunicii), ILS 5049 (Arval Brethren), Tac. Ann. 2.83.2 (sodales Augustales); Rawson 1987: 109, Kolendo 1981: 301-305. 
measure was designed to increase the prestige of the priestesses rather than that of the dowager empress (Ann. 4.16). Livia's repeated association with the privileges of the Vestal virgins reveals just how useful the Vestals were as a model for other uniquely prominent women in public life to follow. It should be kept in mind, of course, that Livia's prominence was due to her position within the family of Augustus and her reputation as an epitome of matronal virtue. ${ }^{83}$

Finally, we must consider the Vestals' ability to act as legal witnesses, which is similar to their exemption from tutela and the right to make a will in that it only appears to have qualified as a privilege in being applied to a group of women in the first place. In another section of the Attic Nights, Gellius refers to the text of an ancient (and possibly apocryphal) lex Horatia, which granted a Vestal named Taracia the privilege of being testabilis, an honor he says was bestowed upon her alone of all women (NA 7.7.2). ${ }^{84}$ With time, the exclusivity of this privilege also came to be erased. Just as women sometimes were able to defy the expectations of their gender and plead cases on their own behalf, evidence from women became an operative reality, though still rare, in the courtrooms of the late Republic. ${ }^{85}$ By the time of Augustus, at least, the expectation that women of good

${ }^{83}$ Severy 2003: 135, cf. Beard 1980: 17.

${ }^{84}$ Cf. Plut. Popl. 8.4, Plin. NH 34.25; Santinelli 1904: 67, Düll 1953: 382-83, Guizzi 1968: 174-76, Beard 1980: 17.

${ }^{85}$ Cic. Verr. 2.1.37, 94 (acknowledged by Beard 1980: 17n.49), also Suet. Jul. 74.2, Val. Max. 8.3.1-3, ILS 8393, 4-26, cf. Ulp. Dig. 3.1.1.5, 50.17.2; Clark 1981: 206, Marshall 1989, Thomas 1992: 137, Bauman 1992: 48-52. 
character could give testimony is implied by the terms of the lex Iulia de adulteriis coercendis, which specified that women convicted of adultery were not allowed to give testimony. ${ }^{86}$ Not only was the privileged status of the Vestals in this arena not exclusive, it could even be surpassed, as Tacitus observed:

ceterum Urgulaniae potentia adeo nimia civitati erat, ut testis in causa quadam, quae apud senatum tractabatur, venire dedignaretur: missus est praetor, qui domi interrogaret, cum virgines Vestales in foro et iudicio audiri, quotiens testimonium dicerent, vetus mos fuerit.

Tac. Ann. 2.34.4 $4^{87}$

Nevertheless, the power of Urgulania was so far beyond the scope of constitutional principles that, when she refused to appear as a witness in a case being conducted before the senate, a praetor was sent to question her at home,

\footnotetext{
${ }^{86}$ As reasoned by Paul, Dig. 22.5.18; Gardner 1986: 129. The contrast with the Vestals, a group of women defined by their extraordinary chastity, is suggestive. Cf. Dig. 22.5.2.5 (Call.), recording a prohibition against testimony from female prostitutes under the lex Iulia de vi: McGinn 1998b: 61-64.

${ }^{87}$ See Goodyear 1981: 295, also Bauman 1992: 135, Mekacher 2006: 28-29. This is a controversial passage, misconstrued by Kroppenberg 2010: 421-22. Wildfang's account (2006: 67-69) is also problematic.
} 
even though it was an ancient custom that Vestal virgins were heard in the forum at the trial whenever they gave testimony.

The core of Tacitus' complaint is not that Urgulania's testimony should have been taken into account (the senate, after all, seems to have requested it). Rather, his concern is with the overweening power (potentia) of this friend of Livia, who could not be bothered to respond to their summons and instead was allowed to give a deposition in her own home. Such deference exceeded even the customary honors accorded to the Vestals, who still had to appear for questioning.

Of all the legal peculiarities that defined the Vestals' special status within Roman society, only the severing of patria potestas seems to have had any meaningful impact on their position within the family. From an early date, the Vestals were exempted from some of the constraints traditionally imposed upon their sex, but each of these privileges was a mark of status that came to be shared with other women over time. Certain privileges, like the use of lictors, carriages, and special seating at the games, were only ever shared with Livia and other women of the imperial household, although each of these honors was also held in common with other priests. The only explanation that accounts for all of these things with any consistency, therefore, is that these were temporal honors that derived from, but did not necessarily constitute, the Vestals' sacred authority. As women entrusted with their own independent role as officials of the state 
religion, the Vestals were necessarily regarded as more reliable than other members of their gender ${ }^{88}$ As a consequence, they could be rendered more self-sufficient as well. ${ }^{89}$ In this context, it may be helpful to consider the case of C. Valerius Flaccus, who was made flamen Dialis against his will in 209 BC. According to Livy (27.8.5-10), he flourished in the role and came to be held in such regard that he was able to reclaim the ancient privilege (vetustum ius sacerdotii) of attending the senate, which had fallen into abeyance because of the unworthiness (indignitas) of previous flamines. ${ }^{90}$ What this story suggests is that certain privileges grew out of a presumption of moral worthiness on the part of Rome's priests, although they were not always regarded as essential elements of their religious identity. This principle accords well with the tradition that Taracia received the right to testify in return for her services to the state, as well as the idea that

${ }^{88}$ Vestals were not, of course, the only public priestesses in Rome. But the significant difference between them and flaminicae and the regina sacrorum was that the Vestals' priesthood did not depend upon their role as wives under the manus of a male priest: Schultz 2006: 80-81. The position of female sacerdotes of Ceres seems to have been more analogous to that of the Vestals, but consideration of their status will be left out of the present discussion, owing to the cult's historic associations with the plebs and its appropriation of Greek-style rites: see Spaeth 1996: 86-96, 103-109, Schultz 2006: 75-79.

${ }^{89}$ Mekacher 2006: 27, Kroppenberg 2010: 423-24, cf. Düll 1953: 383-84, CancikLindemaier 1990: 9, Scheid 1992: 384.

${ }^{90}$ Rüpke 2012: 187. 
the Vestals' exemption from tutela and their consequent ability to make wills were granted out of respect for their priestly status.

\section{CAPTURED MEN}

Because of the unique nature of their priesthood, the Vestals' position within Roman society represented a complicated legal fact, which even lawyers like Gellius and Labeo had difficulty understanding in all of its dimensions. For the purpose of the present discussion, what concerns us most is the Vestals' removal from patria potestas. As has already been noted, this aspect of their legal status was not in itself unique, although the manner in which they acquired it was extraordinary. It happened at the moment of their "capture" into the priesthood, such that the ceremony of initiation might be said to represent the legal equivalent of the various other procedures by which a woman could be rendered sui iuris. Once again, however, the excessively narrow perspective found in some of the recent scholarship on the Vestals has tended to obscure the true nature of this rite by treating it as if it were something that applied to these priestesses alone.

In his explanation for why the term for being captured (capi) is used to describe the process by which a girl is inducted into the Vestal priesthood, Gellius offers a description of the ritual itself:

“Capi" autem virgo propterea dici videtur, quia pontificis maximi manu prensa ab eo parente, in cuius potestate est, veluti bello capta abducitur.

Gell. NA 1.12.13 
It seems that the virgin is said "to be captured" because she is taken in hand by the pontifex maximus from the parent under whose authority she comes and is led away, just like one who is captured in war.

Gellius goes on to quote the antiquarian N. Fabius Pictor's account of the language used by the pontifex maximus on this occasion, in which the verb capio also appears (1.12.14) ${ }^{91}$ The suggestion of an analogy with prisoners of war is intriguing, because patria potestas was also suspended in the case of captivity, only to be restored with the recovery of citizen rights through a grant of postliminium. ${ }^{92}$ This interpretation does not get us very far, however, because Vestals did not suffer a loss of status (capitis deminutio maxima) in the same way that war captives did. Instead, as we have seen, they acquired a slate of new privileges and legal competencies as a result of their ritual "capture" into a priesthood. ${ }^{93}$

Some modern scholars have noted a similarity to Festus' description of the simulated "stealing" of a bride during the wedding ceremony (364 Lindsay), in which the girl is said to be snatched away (rapi) from the lap of her mother or another close female

\footnotetext{
${ }^{91}$ de Sacerdotiis Publicis fr. 4 Huschke.

${ }^{92}$ Watson 1967: 237, cf. Martini 1997: 257, Kroppenberg 2010: 424.

${ }^{93}$ Gardner 1986: 25.
} 
relative. ${ }^{94}$ The analogy is not very approximate, however, and the hypothetical equation of Vestals with brides turns out to be a red herring. The most important objection to this line of reasoning comes from Gellius himself, who in the very next paragraph informs us that the Vestals were not the only priests to whom this term could be applied: "Many think that only a virgin should be said to be captured, but the flamines Diales are also said to be captured, as are the pontifices and augurs" (plerique autem capi virginem solam debere dici putant. sed flamines quoque Diales, item pontifices et augures "capi" dicebantur, 1.12.15). As proof, Gellius offers a quotation from the second book of Sulla's memoirs, in which the dictator's ancestor P. Cornelius Sulla is described as "captured as flamen Dialis" (flamen Dialis captus), as well as a passage from Cato the Elder's speech against Servius Galba. ${ }^{95}$ To these we may add the testimony of Livy, who says that $\mathrm{C}$. Valerius Flaccus "had been captured as flamen by the pontifex maximus P. Licinius on account of his wanton and indulgent youth" before transforming into the exemplary priest that he became (ob adulescentiam neglegentem luxuriosamque C. Flaccus flamen captus a P. Licinio pontifice maximo erat, 27.8.5).

Now, those scholars who regard the "capture" of the Vestal virgins as sui generis can point to the analysis of Guizzi, who noted that flamines were more consistently

\footnotetext{
${ }^{94}$ Dragendorff 1896: 299, Beard 1980: 13-14 (citing Santinelli 1904), Stehle 1989: 148, Scheid 1992: 382, Wildfang 2003: 561; cf. Latte 1960: 109n.4, Hersch 2010: 144-47.

${ }^{95}$ Gell. NA 1.12.16-17. Sulla, fr. 2 Peter. The use of capere in the Cato passage (fr. 109 Peter) probably does not reflect the term's technical usage: Wissowa 1899.
} 
described as being "inaugurated" (inauguratus) rather than "captured" (captus). ${ }^{96}$ The relative variety of the terminology, he argues, reflects a substantial difference between the Vestals and other members of the pontifical college in the way that they became priests. This may be a valid point, but the nature of this difference needs to be considered in greater detail. We know from Gaius and other legal sources that the flamen Dialis, like the Vestal virgins, was also removed from patria potestas without undergoing capitis deminutio. ${ }^{97}$ But unlike the Vestals, who were inducted as prepubescent girls and were required to have both parents alive at the time of their selection, a flamen could be inaugurated after previously being released from patria potestas by other means. For example, the son of Ser. Cornelius Lentulus Maluginensis was chosen to succeed his father as flamen Dialis after the latter's death in AD 23. ${ }^{98}$ Julius Caesar was also selected for the flaminate following his father's death, although he was never actually inaugurated. ${ }^{99}$ If, as Gellius' description suggests, the principal function of one's

${ }^{96}$ Guizzi 1968: 34-45, citing Gai. Inst. 3.114, cf. Wissowa 1899, Martini 1997: 256, Rüpke 2005: 1576. In fact, Livy also says of C. Valerius Flaccus flaminem Dialem invitum inaugurari coegit P. Licinius pontifex maximus (27.8.4, see also 41.28.7, 45.15). ${ }^{97}$ Gai. Inst. 1.130, 3.114, Ulp. Tit. 10.5; Guizzi 1968: 160-62, Wildfang 2006: 69, Watson 1967: 101.

98 Tac. Ann. 4.16.4: et filius Maluginensis patri suffectus; PIR ${ }^{2} \mathrm{C} 1376$.

${ }^{99}$ Suet. Jul. 1.1, cf. Vell. 2.43.1.3, Tac. Ann. 3.58.2. There were, of course, significant irregularities in Caesar's nomination for this priesthood: Taylor 1941: 113-16, Rüpke 2005: 1575-78. 
"capture" by the pontifex maximus was to remove a prospective priest from the potestas of a father, it follows that this ritual would always be required for the Vestals, but would not have been necessary for every flamen. Given likely patterns of paternal mortality, this difference would explain why Vestals are consistently described as being "captured," whereas similar descriptions of male priests occur only rarely. ${ }^{100}$

As this analysis suggests, the ritual "capture" of Vestal virgins can just as easily be seen as a feature that Vestals held in common with certain other priests, instead of a marker of their separation from other women. Acknowledgement of this fact leads us to the further realization that the Vestal's extraordinary legal status derives from the intersection of their priestly status (as members of the pontifical college) and their gender role (as unmarried females). By describing their legal position in his way, I intend to invoke the insights of Kimberlé Crenshaw, who has called attention to the failure of a "single axis framework" (1989: 140) to account for the experiences of Black women in contemporary America. ${ }^{101}$ Just as many of the social and legal disadvantages that Black women encounter in our society are the result of the complex interplay of modern categories of race and gender, so too did the Vestals' unusual legal status derive from their unique position at the intersection of Roman categories of gender and religion. Beard's confusion about supposed "elements of masculine status," as well as the ancient ${ }^{100}$ Saller 1987.

${ }^{101}$ For the usefulness of Crenshaw's theory of "intersectionality" for the study of issues beyond the sphere of Black feminist criticism, see, e.g., Berger and Guidroz 2009, Carbado 2013. 
jurists' uncertainty about the Vestals' capacity to make their own wills underscore the limitations of an approach that views the Vestals as women only, rather than as independent female priests. As unmarried women, the Vestals could not easily fit the role that was assigned to them as priests, and vice versa.

Insofar as this insight relates to the Vestals' position within the Roman family structure, it appears that the effect of being "captured" was the same for them as it was for their male counterparts. Whether "capture" was performed on the flamines or not, their legal position with regard to the family of their birth was identical to that of the Vestal virgins. Like the Vestals, these priests also continued to maintain strong ties with their parents, siblings, et cetera. As has already been noted, one of the honorific inscriptions set up for Terentia Flavola was given by her brother, the flamen Dialis Terentius Gentianus (CIL VI $2144=I L S 4927)$. That Gentianus and his wife are joined in this dedication by his nephew (filius fratris) Lollianus Gentianus further demonstrates the strength of agnatic bonds that would have ceased to exist in their more limited, legal sense. Looking back to the period of the Republic, we may note the mournful epitaph composed for the short-lived flamen Dialis P. Cornelius P. f. Scipio among the Saturnian elogia in the family tomb of the Scipios (CIL VI $1288=I L S 4)$, a dedication that must have been set up by agnatic kin. ${ }^{102}$ More interesting still is the case of the aforementioned C. Valerius Flaccus, who, when elected aedile, was prevented by his position as flamen

\footnotetext{
102 Broughton 1951: 407n.6.
} 
Dialis from swearing the oath required of this office. ${ }^{103}$ The issue was resolved when his brother Lucius was permitted to take the oath on his behalf (iuraret pro fratre, Liv. 31.50.9). It is not necessary to go any further into the evidence to reaffirm the conclusion that meaningful bonds of kinship were not necessarily severed upon one's entry into a priesthood, even if patria potestas was. Even among the elite, there was a concept of family unity that ran deeper than the framework of property and inheritance rights established in the law. ${ }^{104}$

Sulla's interest in his ancestor's "capture" into the flaminate is also consistent with the numismatic commemoration of Vestals like Aemilia and Claudia noted above, but here we must confront the obvious difference between the Vestal virgins and other

${ }^{103}$ Liv. 31.50.7-9, cf. Plut. Mor. 275c-d; Vanggaard 1988: 96-97. In yet another parallel between these priesthoods, Vestals were also forbidden to take oaths: Gell. NA 10.15.31, Fest. 95 Lindsay; Rüpke 2005: 1653, Mekacher 2006: 29, Wildfang 2006: 69, cf. Beard 1980: 18 n.56.

${ }^{104}$ Tryphon. Dig. 37.15.10: nam pietatem liberi parentibus, non operas debent; Saller 1984, 1994: 74-132, Dixon 1988: 13-21. Cf. Ulp. Dig. 50.16.195.1-4. It should be noted, however, that according to the Ulpian's agnatic principle, the position of the Vestals as virgins (discussed in the following section) becomes less extraordinary with the decline of confarreatio marriage, insofar as most women (who did not thereby enter the manus of their husband) remained part of their father's family and were therefore "cut off" from the family of their husbands and children. See Pomeroy 1976, Hallett 1984: 216-18, 235 36, Dixon 1988: 44-46, Thomas 1992: 91-96, Saller 1994: 76. 
priests. ${ }^{105}$ Whereas male priests could marry and produce blood descendants and legitimate heirs, the Vestals were required to abstain from all sexual contact throughout the thirty-year term of their priesthood and therefore could not have had children of their own except in very extraordinary circumstances. ${ }^{106}$ In contrast, the flamen Dialis was required to be married in the ancient ritual of confarreatio. ${ }^{107}$ His wife, who would thus also have been separated legally from agnatic bonds by entering into a marriage with manus, thereby acquired her own (subordinate) priestly position as a flaminica. Vestals, however, were unmarried female priests. ${ }^{108}$ In a culture in which the ideal of marriage as a procreative union was unassailable, the Vestal's celibacy marked them as unusual in a much more profound way than their exemptions from patria potestas and tutela. It is to this aspect of their social position that we now turn.

${ }^{105}$ Cf. Badian 1968: 27-28.

${ }^{106}$ After thirty years, Vestals were theoretically allowed to marry and resume an ordinary existence, but Plutarch (Num. 10.2, cf. Dion. Hal. AR 2.67.2) states that few actually relinquished their priesthood, because those who did came to regret it. In any case, the initial term of service roughly coincided with the fertile phase of a woman's life course: Beard 1980: 14n.2, Saquete 2000: 66-67. ${ }^{107}$ Gell. NA 10.15.22-23, Gai. Inst. 1.112; Boels 1973, Treggiari 1991: 22, Scheid 1992: 401-403, Staples 1998: 78, Holland 2012: 206-207. The rule was adjusted in AD 23 so that the flaminica would only be bound by the manus created by this form of marriage for the purpose of her religious duties: Tac. Ann. 4.16.3.

${ }^{108}$ Vanggaard 1988: 50-54, 91, Schultz 2006: 74-75. 


\section{VIRGINITY IN CONTEXT}

As Cicero's lachrymose portrait of Fonteia's supposed dependence on her brother suggests, it was the Vestals' inability to marry or have children, not their relationships with siblings or parents, that truly set them apart from other women (Font. 47-49). ${ }^{109}$ Not only was their virginity the most distinctive characteristic of their kinship status, it was also the defining feature of their religious identity as a whole. Although flamines might be compelled to abdicate because of carelessness in the performance of their religious duties, a breach of Vestal chastity (incestum) was a matter of extraordinary concern, which typically resulted in grisly deaths for everyone involved. ${ }^{110}$ It is little wonder, then, that almost every discussion of the Vestals' position in Roman society pays close attention to the meaning and purpose of their virginity. Having ascertained the proper relationship between this aspect of the Vestals' identity and other features of their kinship status, we are now in a position to reevaluate the available interpretations of these phenomena.

In this section of the article, I review some of the explanations that have been offered for the Vestals' virginity in the years since Beard's reassessment of their "sexual status." Hildegard Cancik-Lindemaier and Ariadne Staples have argued that the purpose

${ }^{109}$ See above, Section II.A.

${ }^{110}$ Plut. Num. 10.4-7, Dion. Hal. AR 2.67.3-4; Beard 1980: 16, Fraschetti 1984, Staples 1998: 132, Saquete 2000: 93-102, Mekacher 2006: 33-36. Cf. Val. Max. 1.1.4-5, Plut. Marc. 5.3-4; Rüpke 2012: 184. 
of sexual abstinence was to signify the Vestals' isolation from the private interests of the family. Taking this concept farther, Holt Parker has claimed that such isolation was necessary for the priestesses to serve as ritual scapegoats in times of crisis. Beard originally followed a different line, suggesting that the priestesses' virginity served to place them in a liminal status, between the categories of daughter and matron. What all of these arguments have in common is a tendency to conflate virginity (which was a unique feature of the Vestal's religious identity) with "capture" (which was not). By disentangling these strands, it becomes possible to better understand the significance of each in establishing the Vestals' position within Roman society.

\section{A. SYMBOLIC ISOLATION}

One of the consistent themes to emerge from the examination of the Vestals' relationship with their natal kin in Section II of this paper is the value of the priesthood as a source of authority and prestige not just for themselves, but for other members of their families as well. Cicero expected the jurors to exercise lenience toward Fonteius because of his sister's position; the citizens of Athens sought to flatter Aurelius Cotta by honoring his daughter, and so forth. This tendency was noted by Cancik-Lindemaier, who suggested that the reason for the Vestals' removal from the Roman family structure (both in their "capture" and through their enforced virginity) was to create a group of women isolated from the narrow, private obligations of family, who could truly serve the public interests of the community at large (1990: 14-15). Similar arguments, to the effect that 
the Vestals' distinctive legal status was designed to render them "a symbol of the whole," have been offered by Staples (1998: 143-45) and others. ${ }^{111}$

One problem with this explanation, as Cancik-Lindemaier acknowledged (1990: 15), is that the logic that underlies it only manifested itself in failure. To the extent that the experiences of actual Vestal virgins are reflected in our sources, these women do not seem to have considered themselves cut off from the interests of their families. On the contrary, they sought to use the influence they gained as public priestesses to benefit parents, siblings, and others, just as those relatives did what they could to publicize (and thus to bask in the reflected glory of) the special sanctity of their kinswomen. From a historical perspective, at least, the discordant forces of politics and elite competition were as present here as in any other aspect of Roman religion.

Nevertheless, as a purely symbolic reading of the Vestals' legal status, this explanation of the Vestals" "capture" is acceptable. It should be noted, however, that insofar as the flamines and perhaps other members of the pontifical college were also removed from patria potestas, this principle cannot be treated as unique in its application to the Vestals. As a general rule, the "capture" of certain priests (whether male or female) by the pontifex maximus would serve (in theory, at least) to preempt competing claims of authority like those encountered by the younger Q. Fabius Maximus, who had occasion to

${ }^{111}$ Wildfang 2003: 561, 2006: 73-74, Parker 2004: 571-73, Kroppenberg 2010: 422-24, 427. See also Pomeroy 1975: 210. 
weigh his imperium as consul against the deference a son was expected to show his paterfamilias (and gained honor by choosing the former over the latter). ${ }^{112}$

Virginity, on the other hand, was required of the Vestals exclusively, and thus need not be subject to the same explanation. The subordinate position of Roman wives (particularly those under the manus of their husbands) would seem to justify a prohibition against marriage for certain female priests, just as it explains the position acquired by flaminicae and the regina sacrorum through marriage. ${ }^{113}$ It does not explain the strict insistence on virginity for the Vestals, however, as this necessitated the selection of a very young girl who was both patrima et matrima and still under the potestas of a respectable paterfamilias - which is to say a candidate whose sexual purity would have been carefully safeguarded throughout her life. ${ }^{114}$ If the aim were to free Vesta's priestesses not just from patria potestas, but also from the undue influence of husbands and even children, a childless widow could fulfill the requirements just as well. In fact, as Plutarch points out, cultic functions analogous to those of the Vestals were typically

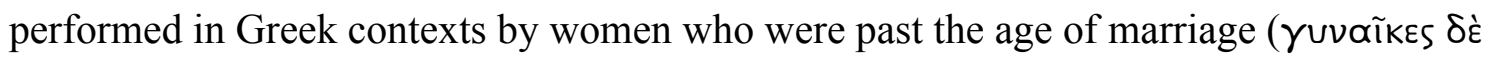

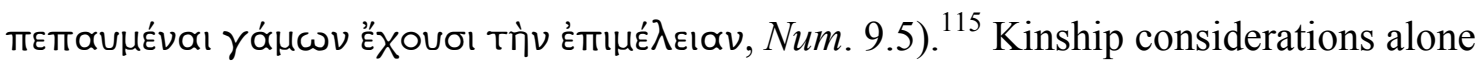
cannot explain the importance of Vestal virginity, let alone the severity of the response to the discovery of incestum.

${ }^{112}$ Liv. 24.44.9-10, Val. Max. 2.2.4, cf. Gell. NA 2.2; Crook 1967: 109.

${ }^{113}$ Cf. Schultz 2006: 80-81.

${ }^{114}$ Cf. Mantle 2002: 105-106.

${ }^{115}$ Martini 2004: 93-94. Cf. Paus. 7.25.13, also 2.10.4, 2.33.2, 7.19.1; Kajava 2004. 


\section{B. FUNCTIONAL ISOLATION}

The limitation of a purely symbolic approach to this question is noted by Parker (2004: 566), who sought to build on the notion of the Vestals' isolation as representatives of the community as a whole by exploring the ideological significance of virginity in greater depth. In a wide-ranging analysis that defies easy summary, Parker makes two claims that are salient for the present discussion. The first concerns the ascribed nature of virginity as a feminine quality, the meaning of which can be inverted by claiming its loss, which serves to transform a chaste and virtuous virgin into a kind of debauched witch when necessary. ${ }^{116}$ Drawing on René Girard's ideas about sacrificial violence, Parker interprets the Vestal condemned for incestum as a "surrogate victim," or scapegoat, against whom communal violence can be directed without incurring vengeance. ${ }^{117}$ Pressing up against Girard's observation that women, in their capacity as wives and daughters, are generally precluded from performing this function, Parker concludes that a female victim "must be exempted from vengeance and removed completely from all social bonds" (1994: 579, cf. Girard 1977: 12-13). This leads to the second relevant claim: "Thus, the special status of the Vestal Virgin made it possible for her to be this perfect victim" (ibid.).

\footnotetext{
${ }^{116}$ Parker 2004: 582, borrowing symbolic types from Giovannini 1981.

${ }^{117}$ Parker 2004: 575-80, Girard 1977: 2-5; cf. Burkert 1979: 59-77. For a different interpretation of the Vestals as victims of human sacrifice, see Baschirotto 2012.
} 
As the material presented in Section II of this article suggests, such an interpretation of the Vestals' legal status dramatically overstates the impact of their removal from patria potestas and tutela. Although a Vestal was legally and thus in some respect symbolically removed from her father's family, the logic of Girard's theory (as Parker construes is) would seem to require a more pronounced repudiation of these connections than what the sources suggest. Furthermore, specific evidence for the handling of accusations of incestum contradicts the notion that endangered or condemned Vestals were so far removed from social bonds that their plight had little impact on their families. In Livy's account of the trial of a Minucia in $337 \mathrm{BC}$, the historian informs us that, in addition to being removed from her ritual duties, the suspect Vestal was also returned to the potestas of her family until her trial could be completed (iussa esset sacris abstinere familiamque in potestate habere, 8.15.8). It has already been noted that the orator Crassus rose to prominence by defending his kinswoman Licinia during the trials of 113 BC (Cic. Brut. 160). It thus seems unwarranted to infer a "total lack of any protest against the sacrifice of a Vestal Virgin, even from the Vestal's family" (Parker 2004: 576) on the basis of the conventionally laconic notices of such events provided in the annalistic tradition. In a fuller, but generalized, account of the procession that carried a condemned Vestal to the place where she was buried alive, Dionysius of Halicarnassus suggests that she would be accompanied by wailing friends and family as if it were her

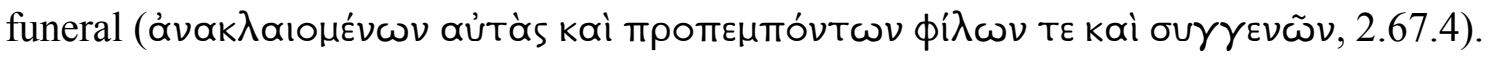

Against the notion that the punishment of an unchaste Vestal constituted a form of human sacrifice, Celia Schultz has pointed out that ancient sources never refer to it as 
such (2010: 531, 2012: 124-27). It should also be noted that the procedure for enacting this "sacrifice," which typically entailed an inquiry by the pontifices in which the accused Vestal might still prove her innocence, seems a rather inefficient mechanism for dealing with the "impure, contagious, reciprocal violence" that stands at the heart of Girard's analysis of myth and ritual (Girard 1977: 49). Although Parker contends that these trials were necessary to produce "absolute faith in the guilt of the surrogate victim," (2004: 585, quoting Girard 1977: 83), his explanation conflates two forms of violence which Girard would place in strict opposition to one another-on the one hand sacrifice, which is directed at a marginal figure in order to escape the cycle of reprisal and vendetta common in primitive society, and on the other hand judicial punishment, which uses the weight of communal authority as manifested in a sovereign system of justice to put a stop to this cycle by assigning responsibility. ${ }^{118}$

Furthermore, the loss of a Vestal's virginity necessarily required the involvement of a second actor, which means that the priestesses typically were not the only "surrogate victims" (however loosely we define the term) in this scenario. The sources are explicit: whereas the unchaste Vestal was traditionally entombed in a chamber beneath the city walls at the Campus Sceleratus near the Porta Capena, the male offender was beaten to death in the Comitium, in the heart of the Roman Forum. ${ }^{119}$ Parker is again misled by

${ }^{118}$ Girard 1977: 15-24, cf. 42.

${ }^{119}$ Plut. Num. 10.4-7, Dion. Hal. AR 2.67.3-4, 8.89.5, 9.40.3-4, Fest. 277 Lindsay; cf. Paul Sent. 2.26.1, 6 on the penalty for male adulterers under the lex Iulia de adulteriis coercendis. 
inadvertent silences in the annalistic record when he asserts the "entirely optional presence of a man" (2004: 581) in prosecutions for incestum. In one of the few cases about which we are relatively well informed - the condemnation of the chief Vestal Cornelia in AD 91-not only do we know the identity of her supposed male corruptor, we are even given a description of the cries of protest that accompanied his public execution. ${ }^{120}$ We should also remember that accusations of involvement in incestum were part of the politicization of the criminal courts in the later years of the Republic, which saw the orator Antonius, Crassus the triumvir, and Catiline all escape condemnation for this most serious of charges. ${ }^{121}$ In later years, the rape of a Vestal would become a convenient charge with which to besmirch the memory of such vicious emperors as Nero and Caracalla. ${ }^{122}$ In these cases, the imputed guilt of the sacrilegious man was at least as important as that of the defiled priestess, if not more so.

Setting aside specific quibbles about the applicability of Girard's ideas about sacrifice and ritual murder to the Roman evidence, it does not help Parker's case that those very ideas (along with the related theories of Walter Burkert, Marcel Detienne, and Jean-Pierre Vernant) have come under increasing attack in recent years from

\footnotetext{
${ }^{120}$ Plin. Ep. 4.11.10: praeterea Celer eques Romanus, cui Cornelia obiciebatur, cum in comitio virgis caederetur, in hac voce perstiterat: "quid feci? nihil feci."

${ }^{121}$ Val. Max. 6.8.1, Plut. Crass. 1.2, Sall. Cat. 15.1.

${ }^{122}$ Suet. Nero 28, Dio 77.2.2-3. Elegabalus, as always, is a special case: Dio 80.9.3, HA Hel. 6.5, Herodian 5.6.2.
} 
anthropologists and scholars of religion. ${ }^{123}$ Nevertheless, it may still be useful to interpret the punishment of unchaste Vestals (and their male corruptores) in times of crisis as a form of therapeutic violence broadly akin to a scapegoat ritual. ${ }^{124}$ If so, we would do better to follow Girard's subsequent reflections on this topic, which made more allowances for the targeting of a "marginal insider," whose position close to the center of power made her as natural an object of popular retribution as the poor or the disabled (Girard 1986: 18-19, cf. 1977: 12). This formulation of the figure of a scapegoat does not require that we ascribe to the Vestals an isolation from their agnatic families that so much of our evidence seems to contradict. It also provides a better fit with the circumstances surrounding the special tribunal established to retry the Vestals who had been acquitted by the pontifical inquiry of $114 \mathrm{BC}$, when popular disapproval was marshaled against a perceived cover-up by the elite to insure that the Vestals met with retribution.

Such occasions were relatively rare, however. For the period surveyed in Section II of this paper, there are four recorded instances of confirmed incestum, which resulted in the deaths of eleven priestesses. ${ }^{125}$ Although the value of the Vestals' virginity

${ }^{123}$ See esp. Jay 1992: 130-33, Knust and Várhelyi 2011: 7-18, also McClymond 2008 and Naiden 2013.

${ }^{124}$ Such an interpretation was already widespread before the appearance of Parker's study. See, e.g., Gruen 1968b: 127, Bauman 1992: 23-24, Staples 1998: 134, also Martini 2004, cf. Wildfang 2006: 79-80.

${ }^{125}$ Liv. Per. 63 (113 BC), Suet. Dom. 8.4 (AD 83 and 91), Dio 77.16 (AD 213); Cornell 1981: 27. 
provided the necessary condition for these persecutions, a scapegoat function does not in itself offer an adequate explanation for the strict regulation of the priestesses' sexuality. In different cultural circumstances, a king might become the scapegoat for his subjects, but a theory of kingship that construes the sovereign as little more than a pharmakos or sacrificial victim in waiting would be inadequate on its face. ${ }^{126}$ The Romans, for their own part, also on occasion resorted to the sacrifice of pairs of Greeks and Gauls - that is to say, victims from outside the community — to resolve similar religious crises. ${ }^{127}$ At other times, a general might "devote" himself to the gods to ensure the success of his army. ${ }^{128}$ However one decides to parse the differences and similarities between these rituals, the identities of the respective human victims - foreigners, generals, and violated virgins - originate in distinctive social roles, each of which had broader cultural implications beyond any sacrificial or scapegoat function. ${ }^{129}$

${ }^{126}$ Lienhardt 1961: 298-319, de Heusch 2005. See also, however, Simonse 1992.

${ }^{127}$ Plin. NH 28.12, Plut. Mor. 284a-c, Marc. 3.3-4, Liv. 22.57.6; Fraschetti 1981, Eckstein 1982, Várhelyi 2007, Schultz 2010, esp. 528-34.

${ }^{128}$ Liv. 8.9.4-12, 10.28.12-18; Versnel 1980, cf. Parker 2004: 587-88.

${ }^{129}$ For distinctions within and among these rituals, see, e.g., Versnel 1972, Várhelyi 2007: 286-90. For the purposes of this argument, it is not necessary to establish whether the burial of an unchaste Vestal constituted a punishment for her supposed crime, human sacrifice, or the elimination of a prodigy: see discussion in Wissowa 1924: 207-208, Cornell 1981: 29-32, Lovisi 1998: 708-12, Staples 1998: 132-34, Schultz 2010, also Martini 1997: 247-48, Parker 2004: 586-88. 


\section{AMBIGUITY}

Beard's groundbreaking investigation of the Vestals" "sexual status" (1980) also emphasized these priestesses' social isolation, but did so in the context of a different theoretical framework. Rather than single out their position relative to normative family structures for special explanation, Beard's analysis brings together multiple aspects of the Vestal's identity in order to situate these things within the framework of Mary Douglas' ideas about ambiguity as a source of religious meaning. ${ }^{130}$ Reframing previous debates about the supposed domestic origins of the Vestal's symbolic associations, Beard concludes that these priestesses "were not either virgins or matrons; they were both, and I have argued, they were also men" (1980: 18). This resistance to conventional categorization is interpreted as playing a fundamental role in setting the Vestals apart from other women and thus establishing their sacred status.

Like the other explanations discussed up to this point, this analysis conflates the Vestal's sexuality and their kinship status in misleading and unhelpful ways. Noting that the priestesses' hairstyle was the same as that worn by brides, Beard comments, "like the girl on the day of her wedding, they are seen as on the brink between virginal and marital status, but perpetually on the brink, perpetually fixed at the moment of transition from one category to another" $(1980: 21) .{ }^{131}$ This image of the Vestals as suspended in a kind

${ }^{130}$ Douglas 1969, 1999: 256-62, also Leach 1976: 34-36.

${ }^{131}$ See Gallia 2014: 225-29, 233-34. On the seni crines, cf. Fest. 454 Lindsay, Hersch 2010: 73-80. 
of sexual Limbo is arresting, but ultimately misleading. Just as there were a number of ways for daughters to pass out of patria potestas, marriage need not always accompany a loss of virginity. Sexually active women could become concubines or prostitutes instead of wives. ${ }^{132}$ Conversely, a bride might in some cases maintain her virginity, because sexual consummation was not legally necessary for Roman marriages to be valid. ${ }^{133}$

Though not necessarily representative of any cultural ideal, these alternatives serve to expose the fundamental problem with any attempt to apply Douglas' theories about interstitiality to the categories of gender and sexuality. It is not that these categories are the products of culture rather than of nature; all categories (and by extension, all ambiguities) are ultimately man-made. ${ }^{134}$ When it comes to the physical manifestations of sex, the reaction to the prodigium of hermaphroditic children (who were ritually drowned by the haruspices) shows that the Romans were perfectly capable of responding with religious awe and even horror to a mixing of categories otherwise imagined to be separate and stable. ${ }^{135}$ Instead, the problem we encounter with the Vestals is that the range of gender roles available within a complex agricultural society such as Rome was too

${ }^{132}$ Treggiari 1981, McGinn 1998b: 70-104.

${ }^{133}$ Ulp. Dig. 24.1.32.13, 35.1.15, cf. Dig. 23.2.5 (Pomp.), 23.2.7 (Paul); Thomas 1992:

119, Hersch 2010: 220-21.

${ }^{134}$ Beard 1980: 20; Douglas 1996: 62, 1999: 255-57, cf. Leach 1964: 33-36, Durkheim and Mauss 1963: 7-9.

${ }^{135}$ Liv. 27.37.5-7, 31.12.6-8; Schultz 2010: 529-30, 2012: 129-31. Cf. Douglas 1969: 3639, Butler 1990: 99-106, Fausto-Sterling 2000. 
involved and too unstable for the logic of sacred ambiguity to find meaningful purchase. ${ }^{136}$ The position of the Vestal virgins, as women who reached puberty without undergoing sexual initiation (whether as brides or otherwise) was not really analogous to that of the prodigious hermaphrodite, let alone the rock badger or another animal that "chews its cud," but lacks "divided hoofs."137

If anything, Beard's identification of a tripartite ambiguity (virgin, matron, and male) only highlights the fact that Roman categories of gender did not necessarily exist in exclusive binary oppositions to one another (cf. Butler 1990: 36-43). Moreover, the lumping together of so many symbolic markers under the loose heading of "sexual ambiguity" does not do justice to the complex ways in which gender roles themselves intersect with other social categories. As I argued above, the peculiarities of the Vestals' legal status must be understood in light of their unique position as women who performed a religious function typically reserved for men. The anomalous intersection thus created does not in itself tell us anything about Roman concepts of taboo or the sacred. What it does shed light on, however, is the underlying complexity and ambivalence of Roman gender categories themselves.

The crux of the matter, however, is that ultimately there was nothing ambiguous about the Vestals" "sexual status" in and of itself. Unlike Roman matrons, who were expected to remain chaste while simultaneously being sexually available to their

\footnotetext{
${ }^{136}$ The nature of the problem becomes clearer if we follow Butler (1990, esp. 128-41) in viewing these roles as performative rather than proscriptive.

${ }^{137}$ Lev. 11:5; Douglas 1969: 41-57, cf. Firmage 1990.
} 
husbands, the Vestals' sexuality was defined by a clear injunction of total abstinence. Beard is therefore correct to insist, "it is unacceptable special pleading to suggest that the virginity of the Vestals was merely representative of a very generalized form of chastity, comparable to the pudicitia of the Roman matron" $(1980: 15) .{ }^{138}$ The failure of this comparison rests more upon our own categories and assumptions than on any which operated in Roman culture, however. ${ }^{139}$ In fact, Cicero argued that the Vestal virgins' chastity (castitas) provided an ideal model for all other women to emulate (Leg. 2.29). In the eyes of Roman men, at least, only males could perform an active sexual role, while women, by definition, were passive objects. ${ }^{140}$ Normal female sexuality was thus defined through its negation, as pudicitia offered the only acceptable form of female subjectivity in this realm. ${ }^{141}$ The ideal of feminine chastity, whether exemplified by virginal Vestals or, in other contexts, the model of Lucretia, reaffirmed the dominance of the sexually active male, even as it served as an instrument of social control within the family. ${ }^{142}$

Just as Girard's ideas about the scapegoat may still be useful once they have been disentangled from Parker's distorting claims about the Vestals' social isolation, so too can Douglas' structuralist approach to ambiguity shed light on the absolute (rather than

${ }^{138}$ Quoted by Parker 2004: 566; see also Staples 1998: 147-48, Kroppenberg 2010: 428, Wildfang 2003: 562-63, Scheid 2001: 28.

${ }^{139}$ See esp. Sissa 1990.

${ }^{140}$ Parker 1997: 48, 55-56, Veyne 1985: 30.

${ }^{141}$ Langlands 2006: 7-8, Gallia 2014: 235-36.

${ }^{142}$ Langlands 2006: 80-96, 143-44. 
ambiguous) nature of the Vestals' sexual purity. Douglas' principal thesis centers on the opposition between concepts of pollution, such as those exemplified in the above-cited "abominations of Leviticus," and holiness, which is pure. In most cases, she argues, the function of religious law is to exclude that which is ambiguous and therefore "dirty" or corrupted. ${ }^{143}$ It is only in extraordinary cases, such as the cult of the scaly yet treedwelling pangolin among the Lele of the Kasai, that anomaly becomes a source of reverence in itself. ${ }^{144}$ In her discussion of purity, however, Douglas was also aware that real life is necessarily messy, particularly when it comes to matters involving sex:

Where sexual purity is concerned it is obvious that if it is to imply no contact between the sexes it is not only a denial of sex, but must be literally barren. It also leads to contradiction. To wish all women to be chaste at all times goes contrary to other wishes and if followed consistently leads to inconveniences of the kind to which Mae Enga men submit.

Douglas 1969: 162

On an alternative reading of Douglas, therefore, the peculiarities of the Vestals' status were not the result of some effort (whether deliberate or unconscious) to mark their

${ }^{143}$ Douglas 1969: 2: "Dirt offends against order. Eliminating it is not a negative movement, but a positive effort to organise the environment." See also Douglas 1999: 106-15.

${ }^{144}$ Douglas 1969: 168-73, 1999: 51-60; cf. Beard 1980: 20. 
sacredness by confounding cultural norms, but were instead the inevitable result of a Roman ideal of female chastity being carried to its logical conclusion. Absolute purity for females would have been impossible to enforce more broadly, but the Vestals, as religiously exalted "symbols of the whole," could be made to pursue this goal on behalf of other women, allowing wives, mothers, and even daughters to "enjoy purity at second hand," as Douglas puts it (1969: 163). Although the Vestals' chastity was what set them apart from other women, it was also, paradoxically, the least ambivalent thing about them.

Carried further, an understanding of the Vestals' castitas as an extreme form of ritual purity helps us to understand not just the severity of the penalty for incestum, but also the way in which it was imposed. The ritual burial of an unchaste Vestal in the underground chamber of the Campus Sceleratus may not have constituted a genuine human sacrifice, but it was not a simple execution, either. ${ }^{145}$ Instead, as Schultz has argued, it should be seen as an act of purification, in which the formerly sanctified but now polluted body of the priestess was removed from the community in order to prevent further contamination (2012: 128-32). It was thus not the Vestals' virginity, but rather the loss of it, that represented the sort of dangerous challenge to normative sexual categories that Douglas' analysis of religious ambiguity can help us understand.

${ }^{145}$ Fest. 448 Lindsay, Livy 8.15.8; LTUR I 225 s.v. “Campus Sceleratus” [Coarelli]. Descriptions of the ritual can be found in Dion. Hal. AR 2.67.4, Plut. Num. 10.4-11; see also Gallia 2012: 113-17. 


\section{CONCLUSION: SPINSTERS AND SOCIETY}

The kinship status of the Vestal virgins was undoubtedly unique, but it was not quite as extraordinary as some scholars have supposed. Their legal removal from patria potestas through the procedure known as "capture" was fundamental to the Vestals' religious position, but it did not impede the continuity of their relationships with the other members of their natal families in any observable way. Furthermore, the authority they gained as female priests only caused their families to value them more, even as this special status set them apart from the program of gender roles generally available to women in Roman society. The true anomaly of the Vestals' kinship status had to do with their virginity, but the fact that they were able to maintain existing family roles while eschewing those of wife and mother shows that these women were neither excluded from nor somehow "on the brink" between normative categories. They simply constituted a category of their own. They were old maids.

Apart from virgin priestesses, spinsters are almost entirely unheard of in discussions of the ancient world. This lack of visibility may be attributed, at least in part, to the nature of our sources. Families would have had little incentive to commemorate daughters who reached adulthood without marrying, or to do so in a way that called attention to this fact. ${ }^{146}$ This does not mean that such women did not exist, however.

${ }^{146}$ Note, for instance, the remarkable preponderance of tombstones set up for young children of both genders in Rome and surrounding areas: Shaw 1987: 34-35, cf. Saller and Shaw 1984: 130, also Shaw 1991: 66-68 on the relative "social valuation" of different gender/age combinations in the commemorative record. Cf. Kowaleski 1999: 
Although encouraged, marriage was not compulsory for men or women. Because consent was required for a marriage to be valid, the mentally incompetent (furiosi) were necessarily debarred from the institution. ${ }^{147}$ Although sexual abstinence was thought in some quarters to be harmful to a woman's health, ancient medical experts were far from univocal on the issue. ${ }^{148}$ Female celibacy was therefore conceivable within the framework of the Roman social structure, even if it was frowned upon and, on the basis of our evidence, decidedly rare.

Demographic pressure was against virginity, of course, as were cultural expectations. ${ }^{149}$ Even Musonius Rufus, who held surprising views on the status of women and the nature of the marital bond, maintained that the primary purpose of marriage was the begetting of children and regarded its avoidance as a threat to "the home, the city, and

39-40 for the invisibility of single women in medieval and early modern Europe, also Farmer 1999: 82-91 on medieval Paris.

${ }^{147}$ Dig. 23.1.8 (Gai.), 23.2.16 (Paul), cf. 23.2.2 (Paul), 29.2.47 (Afr.); Treggiari 1991: 170-80, Watson 1967: 41-45, cf. Pomeroy 1975: 157. The incapacity to wed does not necessarily mean that such people remained celibate, of course, or that they were protected from sexual assault.

${ }^{148}$ Sor. Gyn. 1.30-32, cf. Hippoc. Virg. (8.466-70 Littré), Nat. Mul. 3 (7.316 Littré), Apul. Apol. 69; Foucault 1986: 122, Rousselle 1988: 65-77.

${ }^{149}$ Clark 1981: 195-96, Pomeroy 1975: 164-65, Hopkins 1983: 70-74. 
the whole human race. ${ }^{" 150}$ Christians and other ascetics offered a different perspective, to be sure, but insofar as their views might be relevant to an understanding of Vestal virginity, it is in the proponents' deliberate rejection of the normative ideals of the dominant social order. ${ }^{151}$ Against such outliers, evidence ranging from the oath required by the censors that marriage be undertaken with the aim of producing children to the Augustan legislation that created the ius liberorum for fertile matrons confirms that the Romans understood marriage and procreation as necessary for the continued survival of their community and that they valued these things accordingly. ${ }^{152}$ The perceived need for such regulations (not to mention the fact that the consuls from whom the lex Papia Poppaea took its name were bachelors) also suggests that it was sometimes possible to value other things more highly, however. ${ }^{153}$

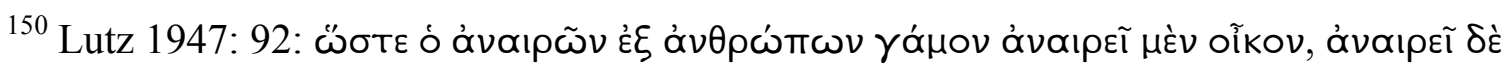

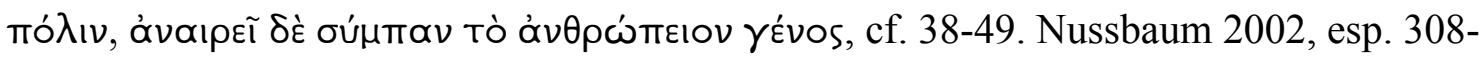
11, Foucault 1986: 150-52, Treggiari 1991: 220-23.

${ }^{151}$ Brown 1987, 1988: 5-9.

${ }^{152}$ Gell. NA 4.3.2, Suet. Aug. 34, cf. Val. Max. 2.9.1, Liv. Per. 59, Treggiari 1991: 8-13, $57-60$.

${ }^{153}$ Dio 56.10.3, cf. Tac. Ann. 15.19, Sen. Marc. 19.2, also Riddle 1992, Pomeroy 1975: 166-68, Dixon 1988: 21-25, 92-96. Note also the attitude of the dedicator of the so-called Laudatio Turiae, who refused to divorce his wife despite the orbitas of their union: ILS 8393 II 31-60. 
It is impossible to say with certainty just how rare spinsterhood was in the Roman world, but for the purposes of the present discussion absolute numbers may be beside the point. Even in historical periods where their presence was more pronounced, unmarried women tend to be treated as anomalies. Christianity was more accommodating of virginity, but in the middle ages, single women who were not in holy orders were generally assumed to be prostitutes, regardless of their real occupation. ${ }^{154}$ In nineteenth and early twentieth century Europe, spinsterhood came to be regarded as a manifestation of sexual deviance that represented a potential threat to the social order. ${ }^{155}$ At the risk of overgeneralizing, it may be worth considering the suspicion in which the Vestals were held in times of religious crisis as part of a much larger pattern of anxiety about sexually unavailable women in male-dominated societies.

Even in times of tranquility, a sense of ambivalence pervaded Roman men's attitudes toward the Vestals and their cult. Rampant speculation about the contents of the inner shrine (penus) of Vesta, a space from which men were excluded, can be understood in this context, just as Clodius' infiltration of the mysteries of Bona Dea-at which women's libidos were supposedly roused through the drinking of wine-seems to reflect a desire to know what went on behind closed doors. ${ }^{156}$ If we regard Roman religion as a

${ }^{154}$ Karras 1999.

${ }^{155}$ Jeffreys 1985, Dollard 2006.

${ }^{156}$ Dion. Hal. AR 2.66.3-6, Plut. Numa 9.8, Camil. 20.3-6; Staples 1998: 152-53, Santinelli 1902: 255-62. Cic. Har. 37, Plut. Caes. 10, cf. Macrob. Sat. 1.12.24-25, Plut. Mor. 268d-e; Versnel 1992: 48-49. 
discourse about identity and the nature of community, the unanswerability of such questions may be part of the point, as Dionysius of Halicarnassus' insistence that one should not look too closely into these matters suggests $(A R 2.66 .6) .{ }^{157}$ But the basis of such morbid curiosity also reveals a great deal about the ingrained misogyny of Roman culture. It certainly cannot have helped matters that the Vestals were said to be responsible for the rites of Fascinus, an apotropaic deity worshipped in the form of a phallus (Plin. NH 28.39). ${ }^{158}$ The suppression of the Vestals' sexuality thus exposed the profound uneasiness inherent in the Roman system of male domination, even as it provided vital ideological support for that very system.

A final point: the analysis presented here has been mostly impersonal, focused on the structures of culture and society. Little consideration has been given to the thoughts or desires of individual Vestals. Even the relationships surveyed in Section II have been viewed primarily from the perspective of male family members who benefitted from the prestige of their Vestal kin. Such an approach is probably the appropriate one, given the distance of time and the limitations of our evidence. But a regrettable drawback of this approach is that it commits us to the perspective of the men who produced most of our

${ }^{157}$ Beard 1995: 174.

${ }^{158}$ Note also the phallic associations of the hearth flame itself (e.g., Plin. NH 36.204, Dion. Hal. AR 4.2.1-3, cf. Varr. LL 5.61), discussed by Beard 1980: 24, Stehle 1989: 149, Staples 1998: 149, also Brelich 1949: 68-75. Cf. also the handling of dough molded into phallic shapes at the Thesmophoria: Schol. Luc. 276 Rabe, Versnel 1992: 38-40. 
sources, and thus to the normative logic of a male-dominated society. ${ }^{159}$ Although we might critique this ideology for its paradoxes and inconsistency, as historians we cannot easily move beyond it. Apart from the role assigned to her in Cicero's courtroom drama, what did Fonteia really think about her place in Roman society, not just as a sister to her brother, but as a sacred representative of the entire community? What about Cornelia, the Vestalis maxima buried alive by Domitian in AD 93, whose insistent declaration of her innocence is quoted in the younger Pliny's account of her punishment? ${ }^{160}$

Although these questions cannot be answered, it is important to pose them, if only to mark the limitations of what we are able to know. Speculation that the women at the heart of the scandals of 114-13 BC were engaged in some sort of rebellion against the small-mindedness and superstition of their day is perhaps better left to the authors of historical novels, but it at least encourages us to think of the Vestals as subjects rather than mere objects of male control by raising the possibility that they viewed their own actions differently from the men who condemned them. ${ }^{161}$ We cannot know if any Vestals regarded their renunciation of a procreative role as an act of empowerment in a

${ }^{159}$ Cf. Jay 1992: 145: "When theory posits a collective subject, some people's subjectivity will be more collective than others', and when theory construes society as one and whole, some people are always going to be more 'social' than those whose voices, if heard, would damage the unity of the model." ${ }^{160}$ Plin. Ep. 4.11.7: multa sed hoc frequentissime clamitabat: "me Caesar incestam putat, qua sacra faciente vicit triumphavit!’ Gallia 2012: 123-26.

${ }^{161}$ Cf. Bauman 1992: 55-57, also Wildfang 2006: 93-94. 
manner similar to that which Origen and other "fathers" of early Christianity mapped onto the lives of such virgin rebels as the martyr Thecla, although this may be worth

considering. ${ }^{162}$ On the other hand, perhaps they truly believed that Rome and its empire would flourish so long as they remained pure, and behaved accordingly. This is probably the most likely scenario, but it also raises another, potentially troubling question: would such an attitude mean that the Vestals were themselves complicit in the ideology of a "male defined idealized womanhood" (Sawyer 1996: 127) that kept them so precariously separated from an ordinary existence?

${ }^{162}$ Brown 1988: 156-77, Castelli 1986, Rousselle 1988: 128-93, Cooper 1996: 45-67. Cf.

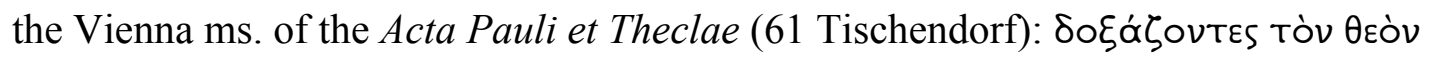

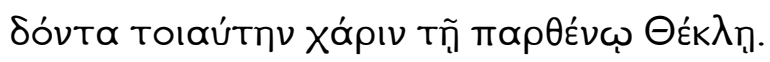




\section{BIBLIOGRAPHY}

Arangio-Ruiz, V., ed. 1943. Fontes Iuris Romani Antejustiniani. Pars Tertia: Negotia. Florence.

Astolfi, R. 1970. La Lex Iulia et Papia. Padua.

Badian, E. 1968. "Sulla's Augurate." Arethusa 1: 26-46.

Baschirotto, S. 2012. "Vesta and the Vestals, Protectors of Rome." In A. Mastrocinque and C. Giuffrè Scibona, eds., Demeter, Isis, Vesta and Cybele: Studies in Greek and Roman Religion in Honour of Giulia Sfameni Gasparro, 165-81. Stuttgart.

Bauman, R. A. 1992. Women and Politics in Ancient Rome. London and New York.

Beard, M. 1980. “The Sexual Status of Vestal Virgins.” JRS 70: 12-27.

-----. 1995. “Re-reading (Vestal) Virginity.” In R. Hawley and B. Levick, eds., Women in Antiquity: New Assessments, 166-77. London.

-----. 2007. The Roman Triumph. Cambridge, MA.

Berger, M. T., and K. Guidroz, eds. 2009. The Intersectional Approach: Transforming the Academy through Race, Class, \& Gender. Chapel Hill.

Boels, N. 1973. "Le Statut Religieux de la Flaminica Dialis.” REL 51: 77-100.

Brelich, A. 1949. Vesta. Zurich.

Broughton, T. R. S. 1951. The Magistrates of the Roman Republic. Volume I: 509 B. C.100 B. C. New York.

----- 1952. The Magistrates of the Roman Republic. Volume II: 99 B. C.-31 B. C. New York. 
Brown, P. 1987. "The Notion of Virginity in the Early Church.” In B. McGinn and J. Meyendorff, eds., Christian Spirituality: Origins to the Twelfth Century, 427-43. New York.

-----. 1988. The Body and Society: Men, Women and Sexual Renunciation in Early Christianity. New York.

-----. 1990. "Bodies and Minds: Sexuality and Renunciation in Early Christianity.” In D. M. Halperin, J. J. Winkler, and F. I. Zeitlin, eds., Before Sexuality: The Construction of Erotic Experience in the Ancient Greek World, 479-93. Princeton.

Burkert, W. 1979. Structure and History in Greek Mythology and Ritual. Berkeley.

Butler, J. 1990. Gender Trouble: Feminism and the Subversion of Identity. New York and London.

Cadoux, T. J. 2005. “Catiline and the Vestal Virgins.” Historia 54: 162-79.

Cancik-Lindemaier, H. 1990. “Kultische Privilegierung und gesellschaftliche Realität: Ein Beitrag zur Sozialgeschichte der Virgines Vestae.” Saeculum 41: 1-16.

Carbado, D. W. 2013. “Colorblind Intersectionality.” Signs 38: 811-45.

Castelli, E. 1986. "Virginity and Its Meaning for Women's Sexuality in Early Christianity." Journal of Feminist Studies in Religion 2: 61-88.

Clark, G. 1981. "Roman Women.” G\&R 28: 193-212.

Cooper, K. 1996. The Virgin and the Bride: Idealized Womanhood in Late Antiquity. Cambridge, MA.

Cornell, T. J. 1981. "Some Observations on the 'crimen incesti." In Le délit religieux dans la cité antique. CEFR 48, 27-37. Rome. 
Crawford, M. H. 1974. Roman Republican Coinage. Cambridge.

-----, ed. 1996. Roman Statutes. BICS Suppl. 64. 2 vols. London.

Crenshaw, K. W. 1989 “Demarginalizing the Intersection of Race and Sex: A Black Feminist Critique of Antidiscrimination Doctrine, Feminist Theory and Antiracist Politics." The University of Chicago Legal Forum 139: 139-67.

Crook, J. A. 1967. Law and Life of Rome. London.

de Heusch, L. 2005. “Forms of Sacralized Power in Africa.” In D. Quigley, ed., The Character of Kingship, 25-37. Oxford.

Dixon, S. 1988. The Roman Mother. Norman, OK.

----. 1991. "The Sentimental Ideal of the Roman Family.” In B. Rawson, ed., Marriage, Divorce and Children in Ancient Rome, 99-113. Oxford.

Dollard, C. 2006. "The alte Jungfer as New Deviant: Representation, Sex, and the Single Woman in Imperial Germany." German Studies Review 29: 107-26.

Douglas, M. 1969. Purity and Danger: An Analysis of the Concepts of Pollution and Taboo. 2nd ed. London.

----- 1996. Natural Symbols: Explorations in Cosmology. 2nd ed. London and New York.

-----. 1999. Implicit Meanings: Selected Essays in Anthropology. 2nd ed. London and New York.

Dragendorff, H. 1896. "Die Amtstracht der Vestalinnen.” RhM 51: 281-302.

Düll, R. 1953. "Privatrechtsprobleme im Bereich der virgo Vestalis." ZRG 70: 380-90. 
Durkheim, E., and M. Mauss. 1963. Primitive Classification. Trans. R. Needham. Chicago.

Eck, W. 2010. "Ehrungen für Personen hohen soziopolitischen Ranges im öffentlichen und privaten Bereich.” In W. Ameling and J. Heinrichs, eds., Monument und Inschrift, 95-125. Berlin.

Eckstein, A. M. 1982. "Human Sacrifice and Fear of Military Disaster in Republican Rome." AJAH 7: 69-95.

Epstein, D. 1986. “Cicero's Testimony at the Bona Dea Trial.” CP 81: 229-35.

Evans-Pritchard, E. E. 1965. "The Position of Women in Primitive Societies and in Our Own." In The Position of Women in Primitive Societies and Other Essays in Social Anthropology, 37-58. London.

Farmer, S. 1999. “"It is Not Good That [Wo]man Should Be Alone': Elite Responses to Singlewomen in High Medieval Paris.” In Bennett and Froide, 82-105.

Fausto-Sterling, A. 2000. Sexing the Body: Gender Politics and the Construction of Sexuality. New York.

Firmage, E. 1990. “The Biblical Dietary Laws and the Concept of Holiness.” In J. A. Emerton, ed., Studies in the Pentateuch, 177-208. Leiden.

Flower, H. 1996. Ancestor Masks and Aristocratic Power in Roman Culture. Oxford.

Foucault, M. 1986. The Care of the Self: Volume 3 of The History of Sexuality. Trans. R. Hurley. New York.

Fraschetti, A. 1981. "Le Sepolture Rituali del Foro Boario.” In Le délit religieux dans la cité antique. CEFR 48, 51-115. Rome. 
-----. 1984. “La Sepolture delle Vestali e la Città.” In Du Chatiment dans la Cité:

Supplices corporels et peine de mort dans le monde antique. CEFR 79: 97-129. Rome.

Frei-Stolba, R. 1998. "Flavia Publicia, virgo Vestalis maxima. Zu den Inschriften des Atrium Vestae.” In P. Kneissl and V. Losemann, eds., Imperium Romanum: Studien zu Geschichte und Rezeption. Festschrift für Karl Christ zum 75. Geburtstag, 233-51. Stuttgart.

Galinsky, K. 1981. “Augustus' Legislation on Morals and Marriage.” Philologus 125: $126-44$.

Gallia, A. B. 2012. Remembering the Roman Republic: Culture, Politics, and History under the Principate. Cambridge.

----. 2014. “The Vestal Habit.” CP 109: 222-40.

Gardner, J. F. 1986. Women in Roman Law and Society. Bloomington.

Geertz, C. 1973. The Interpretation of Cultures. New York.

Giovannini, M. J. 1981. "Woman: A Dominant Symbol within the Cultural System of a Sicilian Town." Man 16: 408-46.

Girard, R. 1977. Violence and the Sacred. Trans. P. Gregory. Baltimore.

----. 1986. The Scapegoat. Trans. Y. Freccero. Baltimore.

Goodyear, F. R. D. 1981. The Annals of Tacitus Books 1-6, Volume II: Annals 1.55-81 and Annals 2. Cambridge.

Gruen, E. S. 1968a. "M. Antonius and the Trial of the Vestal Virgins." RhM 111: 59-63.

----- 1968b. Roman Politics and the Criminal Courts, 149-78 B.C. Cambridge, MA. 
Guizzi, F. 1968. Aspetti giuridici del sacerdozio Romano: Il sacerdozio di Vesta. Naples.

Hallett, J. P. 1984. Fathers and Daughters in Roman Society: Women and the Elite Family. Princeton.

Hersch, K. K. 2010. The Roman Wedding: Ritual and Meaning in Antiquity. Cambridge.

Holland, L. L. 2012. “Women and Roman Religion.” In S. L. James and S. Dillon, eds., $A$ Companion to Women in the Ancient World, 204-14. London.

Hopkins, K. 1983. Death and Renewal. Sociological Studies in Roman History Volume 2. Cambridge.

Jay, N. 1992. Throughout Your Generations Forever: Sacrifice, Religion, and Paternity. Chicago.

Jeffreys, S. 1985. The Spinster and Her Enemies: Feminism and Sexuality 1880-1930. London and Boston.

Jordan, H. 1886. Der Tempel der Vesta und das Haus der Vestalinnen. Berlin.

Kajava, M. 2004. "Hestia: Hearth, Goddess, and Cult.” HSCP 102: 1-20.

Karras, R. M. 1999. "Sex and the Singlewoman.” In J. M. Bennett and A. M. Froide, eds., 1999. Singlewomen in the European Past, 1250-1800, 127-45. Philadelphia.

Kaster, R. 2005. Emotion, Restraint and Community in Ancient Rome. Oxford.

Knust, J. W., and Z. Várhelyi. 2011. "Introduction: Images, Acts, Meanings and Ancient Mediterranean Sacrifice.” In Ancient Mediterranean Sacrifice, 3-31. Oxford.

Kolendo, J. 1981. "La répartition des places aux spectacles et la stratification sociale dans l’Empire Romain." Ktema 6: 301-15. 
Kowaleski, M. 1999. "Singlewomen in Medieval and Early Modern Europe: The Demographic Perspective.” In Bennett and Froide, eds., 38-81. Philadelphia.

Kroppenberg, I. 2010. "Law, Religion, and Constitution of the Vestal Virgins." Law and Literature 22: 418-39.

Langlands, R. 2006. Sexual Morality in Ancient Rome. Cambridge.

Latte, K. 1960. Römische Religionsgeschichte. Munich.

Leach, E. 1964. “Anthropological Aspects of Language: Animal Categories and Verbal Abuse.” In E. H. Lenneberg, ed., New Directions in the Study of Language, 23-63. Cambridge, MA.

----- 1976. Culture and Communication: The Logic by which Symbols are Connected. Cambridge.

Lienhardt, G. 1961. Divinity and Experience: The Religion of the Dinka. Oxford.

Lovisi, C. 1998. "Vestale, incestus et juridiction pontificale sous la république romaine." MEFRA 110: 699-735.

Lucchi, G. 1968. "Sul significato del carpentum nella monetazione romana imperiale.” RIN 5th ser., 16: 131-41.

Lutz, C. E. 1947. "Musonius Rufus: The Roman Socrates.” YCS 10: 3-147.

Mantle, I. C. 2002. “The Roles of Children in Roman Religion.” G\&R 49: 85-106.

Marshall, A. J. 1989. "Ladies at Law: The Role of Women in the Roman Civil Courts." SLLRH 5: 35-54.

Martini, M. C. 1997. “Carattere e struttura del sacerdozio delle Vestali: Un approccio storico-religioso.” Latomus 56: 245-63, 477-503. 
----. 2004. Le vestali. Un sacerdozio funzionale al "cosmo" romano. Brussels.

McClymond, K. 2008. Beyond Sacred Violence: A Comparative Study of Sacrifice. Baltimore.

McDougall, J. I. 1992. "Cassius Ravilla and the Trial of the Vestals." AHB 6.1: 10-17.

McGinn, T. A. J. 1998a. "Feminae Probrosae and the Litter." CJ 93: 241-50.

----. 1998b. Prostitution, Sexuality, and the Law in Ancient Rome. Oxford.

Mekacher, N. 2006. Die vestalischen Jungfrauen in der römischen Kaiserzeit. Wiesbaden.

Mekacher, N., and F. van Haeperen. 2003. "Le choix des vestales, miroir d'une société en évolution (IIIe s. a.C. - Ier s. p.C.)." RHR 220: 63-80.

Münzer, F. 1920. Römische Adelsparteien und Adelsfamilien. Stuttgart.

-----. 1937. “Die römischen Vestalinnen bis zur Kaiserzeit.” Philologus 92: 47-67, 199222.

Naiden, F. S. 2013. Smoke Signals for the Gods: Ancient Greek Sacrifice from the Archaic through Roman Periods. Oxford.

Nock, A. E. 1930. “A Diis Electa: A Chapter in the Religous History of the Third Century." HTR 23: 251-74. (= Essays on Religion and the Ancient World. Vol. I, 252-70. Cambridge, MA.)

North, H. F. 2000. "Lacrimae Virginis Vestalis.” In S. K. Dickison and J. P. Hallett, eds., Rome and Her Monuments: Essays on the City and Literature of Rome in Honor of Katherine A. Geffcken, 357-67. Wauconda, IL. 
Nussbaum, M. C. 2002. “The Incomplete Feminism of Musonius Rufus, Platonist, Stoic, and Roman.” In M. C. Nussbaum and J. Sihvola, eds., The Sleep of Reason: Erotic Experience and Sexual Ethics in Ancient Greece and Rome, 283-326. Chicago.

Palmer, R. E. A. 1971. “Aurelius Cotta.” AJP 92: 55.

Parker, H. N. 1997. “The Teratogenic Grid.” In J. P. Hallett and M. B. Skinner, eds., Roman Sexualities, 47-65. Princeton.

-----. 2004. "Why Were the Vestals Virgins? Or the Chastity of Women and the Safety of the Roman State." AJP 125: 563-601. (Repr. in B. MacLachlan and J. Fletcher, eds., 2007. Virginity Revisited: Configurations of the Unpossessed Body, 66-99. Toronto.)

Pomeroy, S. B. 1975. Goddesses, Whores, Wives, and Slaves: Women in Classical Antiquity. New York.

-----. 1976. “The Relationship of the Married Woman to her Blood Relatives in Rome.” AncSoc 7: 215-27.

Purcell, N. 1983. “The Apparitores: A Study of Social Mobility.” PBSR 51: 125-73.

-----. 1986. "Livia and the Womanhood of Rome.” PCPS n.s. 32: 78-105.

Rawson, E. 1987. “Discrimina Ordinum: The Lex Julia Theatralis.” PBSR 55: 83-114.

Riccobono, S., ed. 1941. Fontes Iuris Romani Antejustiniani. Pars Prima: Leges. Florence.

Riddle, J. M. 1992. Contraception and Abortion from the Ancient World to the Renaissance. Cambridge, MA. 
Rose, H. J. 1926. “De Virginibus Vestalibus.” Mnemosyne 54: 440-48.

Rousselle, A. 1988. Porneia: On Desire and the Body in Antiquity. Oxford.

Rubin, G. 1975. “The Traffic in Women: Notes on the 'Political Economy' of Sex.” In R.

R. Reiter, ed., Toward an Anthropology of Women, 157-210. New York and London.

Rüpke, J. 2005. Fasti Sacerdotum. Die Mitglieder der Priesterschaften und das sakrale Funktionspersonal römischer, griechischer, orientalischer und jüdischchristlicher Kulte in der Stadt Rom von 300 v. Chr. bis 499 n. Chr. 3 vols. Stuttgart.

----. 2012. "Flamines, Salii and the priestesses of Vesta: Individual Decision and Differences of Social Order in Late Republican Roman Priesthoods.” In A. Mastrocinque and C. Giuffrè Scibona, eds., Demeter, Isis, Vesta and Cybele: Studies in Greek and Roman Religion in Honour of Giulia Sfameni Gasparro, 183-94. Stuttgart.

Sacchi, O. 2003. “Il privilegio dell'esenzione dalla tutela per le Vestali (Gai. 1.145). Elementi per una datazione tra innovazioni legislative ed elaborazione giurisprudenziale." RIDA 50: 317-59.

Saller, R. P. 1984. “"Familia, Domus, and the Roman Conception of the Family.” Phoenix 38: 336-55.

----. 1987. "Men's Age at Marriage and its Consequences in the Roman Family." CPh 82: $21-34$.

----. 1994. Patriarchy, Property and Death in the Roman Family. Cambridge. 
Saller, R. P., and B. D. Shaw. 1984. "Tombstones and Roman Family Relations in the Principate: Civilians, Soldiers and Slaves.” JRS 74: 124-56.

Santinelli, I. 1902. "Alcune questioni attinenti ai riti delle vergini Vestali." RivFil 20: 255-69.

-----. 1904. "La condizione giuridica delle Vestali.” RivFil 32: 63-82.

Saquete, J. C. 2000. Las Virgenes Vestales: Un sacerdocio femenino en la religión pública Romana. Madrid.

Sawyer, D. F. 1996. Women and Religion in the First Christian Centuries. London and New York.

Scardigli, B. 2003. "Vestali integrante nella società romana.” SHHA 21: 97-104.

Scheid, J. 1992. “The Religious Roles of Roman Women.” Trans. A. Goldhammer. In P. Schmitt Pantel, ed., A History of Women in the West. Vol. I: From Ancient Goddesses to Christian Saints, 377-408. Cambridge, MA.

----. 2001. "Claudia the Vestal Virgin.” Trans. L. Lappin. In A. Fraschetti, ed., Roman Women, 23-33. Chicago.

Schultz, C. E. 2006. Women's Religious Activity in the Roman Republic. Chapel Hill.

-----. 2010. “The Romans and Ritual Murder.” JAAR 78: 516-41.

-----. 2012. “On the burial of unchaste Vestal Virgins.” In M. Bradley, ed., Rome, Pollution and Propriety: Dirt, Disease and Hygiene in the Eternal City from Antiquity to Modernity, 122-35. Oxford.

Severy, B. 2003. Augustus and the Family at the Birth of the Roman Empire. London and New York. 
Shaw, B. D. 1987. "The Age of Roman Girls at Marriage: Some Reconsiderations.” JRS 77: 30-46.

-----. 1991. "The Cultural Meaning of Death: Age and Gender in the Roman Family." In E. I. Kertzer and R. P. Saller, eds., The Family in Italy from Antiquity to the Present, 66-90. New Haven.

Simonse, S. 1992. Kings of Disaster: Dualism, Centralism and the Scapegoat Kin in Southeastern Sudan. Studies in Human Society 5. Leiden.

Sissa, G. 1990. Greek Virginity. Trans. A. Goldhammer. Cambridge, MA.

Spaeth, B. S. 1996. The Roman Goddess Ceres. Austin, TX.

Staples, A. 1998. From Good Goddess to Vestal Virgins: Sex and Category in Roman Religion. London and New York.

Stehle, E. 1989. "Venus, Cybele, and the Sabine Women: The Roman Construction of Female Sexuality." Helios 16: 143-64.

Syme, R. 1949. "Personal Names in Annals I-VI.” JRS 39: 6-18. (= Ten Studies in Tacitus, 58-78.)

-----. 1986. The Augustan Aristocracy. Oxford.

-----. 1991. Roman Papers. Volume VII. Ed. A. R. Birley. Oxford.

Tarlow, S. 1999. Bereavement and Commemoration: An Archaeology of Mortality. Oxford.

Taylor, L. R. 1941. “Caesar's Early Career.” CPh 36: 113-32.

Thomas, Y. 1992. "The Division of the Sexes in Roman Law.” Trans. A. Goldhammer. In Schmitt Pantel, ed., 83-137. Cambridge, MA. 
Treggiari, S. 1981. “Concubinae.” PBSR 49: 59-81.

-----. 1991. Roman Marriage: Iusti Coniuges from the Time of Cicero to the Time of Ulpian. Oxford.

-----. 2007. Terentia, Tullia, and Publilia: The Women of Cicero's Family. London and New York.

Vanggaard, J. H. 1988. The Flamen: A Study of the History and Sociology of Roman Religion. Copenhagen.

Van Haeperen, F. 2002. Le Collège Pontifical (3ème s. a. C-4ème s. p. C.): Contribution à l'étude de la religion publique romaine. Brussels.

Várhelyi, Z. 2007. “The Specters of Roman Imperialism: The Live Burials of Gauls and Greeks at Rome.” CA 26: 277-304.

Versnel, H. S. 1972. “Two Types of Roman Devotio.” Mnemosyne 29: 365-410.

-----. 1980. "Self-Sacrifice, Compensation and the Anonymous Gods." In Le Sacrifice dans l'antiquité. Etretiens Hardt 27, 135-85. Geneva.

-----. 1992. “The Festival for Bona Dea and the Thesmophoria.” $G \& R$ 39: 31-55.

Veyne, P. 1978. “La familie et l'amour sous le Haut-Empire romain.” Annales HSS 33: $35-63$.

-----. 1985. “Homosexuality in Ancient Rome.” Trans. A. Forster. In P. Ariès and A. Béjin, eds., Western Sexuality: Practice and Precept in Past and Present Times, 26-35. Oxford.

Wallace Hadrill, A. 1981. "Family and Inheritance in the Augustan Marriage-laws." PCPS 27: 58-80. 
Ward, A. M. 1977. Marcus Crassus and the Late Roman Republic. Columbia, MO.

Watson, A. 1967. The Law of Persons in the Later Roman Republic. Oxford.

----. 1971a. Roman Private Law around 200 BC. Edinburgh.

----. 1971b. The Law of Succession in the Later Roman Republic. Oxford.

Wildfang, R. L. 2003. “Why Were the Vestals Virgin?” In P. Defosse, ed., Hommages à Carl Deroux III. Coll. Lat. 270, 557-64. Brussels.

-----. 2006. Rome's Vestal Virgins: A Study of Rome's Vestal Priestesses in the Late Republic and Early Empire. London and New York.

Wissowa, G. 1899. “Capere (2).” RE 3.2: 1509.

-----. 1912. Religion und Kultus der Römer. 2nd edn. Munich.

-----. 1924 "Vestalinnenfrevel.” ARW 22: 201-14. 
$\underline{\text { Image Caption }}$

Figure 1: Denarius of M. Lepidus (61 BC), depicting veiled portrait of the Vestal Aemilia on obverse. RRC 419/3B. (C) Trustees of the British Museum. 
